\title{
O "PROGRAMA DO MOVIMENTO DAS FORÇAS ARMADAS": O SINGULAR DESTINO DA CONSTITUIÇÃO REVOLUCIONÁRIA DO 25 DE ABRIL DE 1974 EM PORTUGAL
}

\section{THE “ PROGRAMA DO MOVIMENTO DAS FORÇAS ARMADAS" : THE ORIGINAL HISTORY OF THE REVOLUTIONARY CONSTITUTION OF PORTUGAL'S 25TH APRIL 74}

Ricardo Leite Pinto

Universidade Lusíada de Lisboa

SUMÁRIO: INTRODUÇÃO ; I. O 25 DE ABRIL ATRAVÉS DO DIÁRIO DO GOVERNO: ONDE ESTÁ O PROGRAMA DO MFA ?- II. A VERTIGEM ( E OS EQUÍVOCOS) DA REVOLUÇÃO PELA IMPRENSA: DOIS PROGRAMAS DO MFA?- III. AS VERDADEIRAS ORIGENS, TRANSFORMAÇÃO E O DESTINO DO PROGRAMA DO MFA: A “ LETRA", O “ NÚCLEO FUNDAMENTAL” , OS “ PRINCÍPIOS” E O “ ESPÍRITO”- IV. A REFLEXÃO HISTÓRICA E POLÍTICA SOBRE O PROGRAMA DO MFA: AS FORÇAS ARMADAS E O PODER POLÍTICO - V. O PAPEL DO PROGRAMA DO MFA COMO ACTO CONSTITUCIONAL DO ESTADO NA FASE TRANSITÓRIA ; 5.1. O Programa do MFA e as leis constitucionais transitórias 5.2. A legislação transitória como execução do Programa do MFA 5.3. O Programa do MFA, as decisões pré-constituintes e a teoria do poder constituinte 5.4. O Programa do MFA , a Assembleia Constituinte e a Constituição de 1976. - VI. CONCLUSÃO

Resumo: O "Programa do Movimento das Forças Armadas", dado a conhecer na manhã do dia 26 de Abril de 1974, após o derrube da ditadura salazarista/ caetanista em Portugal, é um documento político e jurídico original, quer na História Constitucional portuguesa quer mesmo na História Constitucional mundial. Será a Constituição Política da Revolução ( 1974-1976) , invocado por tudo e todos, mas também desrespeitado, e acabará referenciado discretamente na Constituição Portuguesa de 1976. Mas não fosse o Programa do MFA não teríamos seguramente a democracia constitucional que hoje existe em Portugal .

\begin{abstract}
The "Programa do Movimento das Forças Armadas" published by the press in the morning of the 26 th April 74 , after the fall of the Salazar and Caetano dictatorships by the Armed Forces, is a very original juridical and political document at the light of the Portuguese and even Global Constitutional History . It represents the first Political Constitution of the Revolution ( 19741976), addressed to all but also largely disrespected. This Political Constitution of the Revolution will be discretely referenced in the 1976 Portuguese Constitution. If it were not for the " Programa do MFA" the Portuguese constitutional
\end{abstract}


democracy, present currently in Portugal, would be completely different and probably would have never existed.

Palavras Chave: Programa do M.F.A., Revolução do 25 de Abril, Revolução, Constituição, Decisões pré-constituintes

Key Words: " Programa do MFA", "revolution of 25th April ", Revolution"” Constitution" "Pre-constituent decisions"

\section{INTRODUÇÃO}

O golpe de estado/ revolução do 25 de Abril em Portugal completou este ano 42 anos. Se quase tudo já foi dito sobre as origens do movimento militar, os seus responsáveis, a evolução político-militar subsequente, os golpes e contra-golpes de 28 de Setembro, 11 de Março e 25 de Novembro , e mesmo sobre papel dos partidos políticos, dos movimentos operários e sindicais e das potências estrangeiras parece que nem tudo foi dito sobre a importância histórica, politica e jurídico-constitucional do Programa do MFA. Este constitui um documento único e inédito na história política e constitucional portuguesa e mesmo mundial, será a Constituição Política da Revolução, invocado( mas também desrespeitado) por tudo e todos, e no fim acabará referenciado discretamente na Constituição de 1976. Mas a verdade é que se não fosse o Programa do MFA não teríamos seguramente a democracia constitucional em que hoje Portugal vive .

Resgatar do esquecimento esse documento é o propósito deste texto.

\section{O 25 DE ABRIL ATRAVÉS DO DIÁRIO DO GOVERNO: ONDE ESTÁ O PROGRAMA DO MFA?}

Tomemos como referência a hipótese de Miguel Galvão Teles que a propósito do tema "A revolução e o Direito", relata a experiência de alguém, curioso da história pátria e que alguns anos após o 25 de Abril tropeça no Diário do Governo ( jornal oficial) da época ${ }^{1}$. O que leria então ? No diário do 25 de Abril de 1974 encontraria um Decreto proveniente do Ministro da Defesa Nacional, Joaquim Moreira da Silva Cunha que sujeitava a servidão militar a Estação de Satélites da NATO instaladas perto de Sesimbra. O mesmo Ministro que à hora em que o Diário do Governo era distribuído como habitualmente por todas as repartições do país, fugia através de um buraco feita na parede do seu Ministério ${ }^{2}$ acossado pelos militares acabados de chegar ao Terreiro do Paço liderados por Salgueiro Maia. Mas, continuando a ler, o nosso curioso pela história portuguesa constata que essa mesma edição de 25 de Abril contém um Suplemento, esse sim cheio de novidades políticas. Um movimento militar terá tomado o poder e ao abrigo de um intitulado Programa do " Movimento das Forças Armadas Portuguesas" uma auto designada Junta de Salvação Nacional, presidida por

\footnotetext{
1 Vide Miguel Galvão Teles, " A Revolução Portuguesa e as Fontes de Direito" Portugal : O

2 Vide Fernando Pereira Marques, “Sete Noites, Sete dias” in Do Marcelismo ao Fim do Império ( J.M. Brandão de Brito, org.), Lisboa, Notícias Editorial, 1999
} 
António de Spínola, elabora e manda publicar leis e decretos -lei. Em rigor uma Lei e quatro decretos-lei. A Junta de Salvação Nacional não existe obviamente enquanto órgão de poder na Constituição de 1933. Mas a Constituição de 1933 também não é convocada para coisa nenhuma. Ou seja, da leitura dessa histórica edição do Diário do Governo, é possivel concluir , temerariamente , o seguinte :

a) que a Junta de Salvação Nacional assumiu poderes constituintes; na verdade no proémio da Lei $\mathrm{n}^{\circ} 1 / 74$ de $25 / 4$ pode ler-se que : " ... a Junta de Salvação Nacional decreta para valer como lei constitucional o seguinte : " ;

b) que a Junta de Salvação Nacional assumiu, além disso, a quase totalidade dos poderes do Estado, designadamente os poderes politicos, legislativos e executivos do Presidente da República, do Presidente do Conselho, dos Ministros, Secretários e Subsecretários de Estado ( logo do Governo ) da Assembleia Nacional e do Conselho de Estado e isso mesmo decorre do art. $2^{\circ}$ da mesmíssima Lei ;

c) que de entre os poderes do Estado o único a que se não faz referência é ao poder judicial e aos tribunais, assim como nada se diz quanto à Câmara Corporativa, órgão político consagrado na Constituição de 1933;

d) que a nova lei constitucional é de carácter orgânico, concentrando de forma absoluta num directório ${ }^{3}$ - de que não se sabe o número, nem concretamente quem o integra, para além do seu Presidente, António de Spínolaa quase totalidade dos poderes soberanos do Estado.

e) que o novo poder tem a preocupação de destituir ou exonerar de funções os principais dirigentes políticos, e concretiza-o efectivamente, a saber o Presidente da República Almirante Américo Tomás, o Presidente do Conselho Doutor Marcelo Caetano, todos os restantes membros do Governo, os Governadores Gerais de Angola e Mocambique e os Governadores Civis;

f) que esse mesmo poder extingue desde logo a Direcção Geral de Segurança , polícia politica do regime salazarista/ caetanista ( com uma particular excepção para o Ultramar, onde permanecerá " depois de saneada " e reorganizada como "Polícia de Informação Militar", Decreto-Lei n ${ }^{\circ} 171 / 74$ de 25 de Abril, e extingue também a Legião Portuguesa, a Mocidade Portuguesa masculina e feminina e o Secretariado para a Juventude ;

g) e , finalmente, que dissolve a Acção Nacional Popular , " partido político" único do regime derrubado;

Contudo, o nosso improvisado historiador confrontado com o Diário de Governo acabado de ler não deixará de se interrogar:

a) onde está esse aparentemente tão decisivo "Programa do Movimento das Forças Armadas Portuguesas", ao abrigo do qual tudo parece ter sido feito?

\footnotetext{
${ }^{3}$ A estrutura e composição da Junta de Salvação Nacional na sua primeira fase, ou seja até à Lei $n^{\circ} 3 / 74$ constitui uma excepção à natureza dualista do poder militar que vai prevalecer durante a fase transitória. Vide Giuseppe Vergottini. Le Origine della Seconda Repubblica Portoghese, Milão, 1977, p. 219.
} 
b) a ausência de referência à Câmara Corporativa, sendo este órgão tão ilustrativo do regime salazarista, tem algum significado ?

c) e quem são, afinal, os elementos da Junta de Salvação Nacional , para além do seu Presidente ?

Se continuará a ler o Diário do Governo dos dias seguintes só terá resposta à primeira e segundas perguntas no jornal do dia 14 de Maio. Mas quanto à terceira pergunta poderá continuar a ler as sucessivas edições sem parar até aos dias de hoje que nunca encontrará resposta ...

Para já e antes de procurar por outra via saciar a sua curiosidade o nosso historiador constatará, ainda pela leitura do Diário de Governo, que a Junta de Salvação Nacional exercerá sem reservas os amplíssimos poderes que ela própria a si conferiu por via do citado art. $2^{\circ}$ da Lei $1 / 74$.

Alguns exemplos :

a) pelo Dec.Lei $\mathrm{n}^{\circ} 173 / 74$ de $26 / 4$ amnistiou os crimes políticos e as infrações disciplinares da mesma natureza e determinou a reintegração nas funções de todos aqueles que tivessem sido demitidos, reformados ou passados à reserva por motivos de natureza política e pelo Dec.Lei $n^{\circ}$ 194/74 de 10/5 amnistiou , com alguns limites, os crimes essencialmente militares e militares praticados até ao 25 de Abril;

b) criou junto dos Ministérios civis o cargo de " delegado da Junta de Salvação Nacional " com poderes para " assegurar o regular andamento dos serviços e levar ao conhecimento da Junta qualquer assunto que exija resolução imediata", podendo praticar actos da competência dos Ministros - Dec.Lei $\mathrm{n}^{\circ}$ 174/ 74 de 27/4 e Dec.Lei n ${ }^{\circ} 192 / 74$ de 7/6 ;

c) instituiu um novo feriado, o dia 1 de Maio " Dia do Trabalhador"- Dec. Lei $\mathrm{n}^{\mathrm{o}} 175 / 74$ de $27 / 4$;

d) exonerou os Reitores, Vice-Reitores, Directores e Sub-Directores de todas as Universidades, Faculdades e Escolas Superiores do país - Dec.lei $\mathrm{n}^{\circ} 176 / 74$ de $29 / 4$;

e) criou novos organismos ou departamentos administrativos, como são os casos do Fundo do Fomento Cultural - Portaria $n^{\circ} 332 / 74$ de 6/5 - , da Comissão de Controlo do Comércio Externo , junto do Ministério das Finanças- Dec.lei $\mathrm{n}^{\circ}$ 191/74 de 6/5 e , no âmbito do Ministério da Educação Nacional , o Fundo de Apoio aos Organismos Juvenis ( FAOJ) - Dec-lei nº179/74 de 30/4 ;

f) aprovou um regime jurídico de natureza penal para as práticas ilegais relacionadas com operações cambiais, de capitais, notas e moedas e metais ou bens preciosos- Dec.Lei $n^{\circ} 181 / 74$ de 2/5;

g) legislou sobre o uso e aceitação dos cheques bancários - Dec.Lei $\mathrm{n}^{\circ} \mathrm{s}$ $182 / 74$ de $2 / 5$ e 184/74 de 4/5, sobre limites ao levantamento em numerário de contas bancárias - Dec.Lei $n^{\circ} 185 / 74$ de $6 / 5$ e sobre letras, livranças e extractos de factura- Dec-Lei $n^{\circ} 186 / 74$ de 6/5;

h) previu a possibilidade de mediante despacho da própria Junta determinar a suspensão temporária do exercício de funções " de qualquer servidor do Estado- Dec.Lei no $193 / 74$ de 9/5 
Ou seja, facilmente se constata pela simples leitura do Diário de Governo, que o novo e único órgão político pós 25 de Abril do Estado Português ao mesmo tempo que procura afirmar o seu poder indicando delegados com poderes equivalentes aos ministros em todos os Ministérios civis, dá sinal da preocupação ao repor a justiça a todos os que foram perseguidos e condenados pelo regime anterior. Paralelamente, e talvez com maior premência, procura estabilizar a vida da máquina administrativa do Estado, visando sobretudo dominar as perturbações na esfera económica pelas tentativas - quem sabe se não já em execução - da fuga de capitais e bens e da ruptura do abastecimento de bens essenciais à população . E isto, sem esquecer, é claro essa decisão rica de simbolismo, mas não destituída de efeitos práticos, que foi a consagração do " Dia do Trabalhador" como feriado nacional ${ }^{4}$.

Estas três curtas curiosas semanas- entre 25 de Abril e 14 de Maio- em que a História acelerou como não havia memória em Portugal, assim vistas pelo nosso improvisado historiador através do Diário do Governo são o retrato de uma Revolução, disso ninguém duvidará, em que a emergência na resolução de uma imensidão de previstas e não previstas perturbações politicas, económicas e sociais, não se compadece com demoras ou excessivas reverências ao Direito. Apesar de tudo essa revolução é bem diferente daquelas que no sec. XX ocorreram em Portugal, quer a 5 de Outubro de 1910 quer a 28 de Maio de 1926. $\mathrm{E}$ isso o nosso historiador já pôde intuir pelo que leu. Essa diferença, entre outras aspectos, passa justamente pelo Direito Constitucional. Mas diante voltaremos a esses aspectos.

Mas continuemos.

Para já é só pela leitura do Diário do Governo de 14 de Maio que o nosso candidato a historiador encontra resposta para algumas das suas dúvidas. Não todas é claro.

Nesse jornal são publicadas duas leis com valor constitucional aprovadas pela JSN : a Lei 2/74 que extingue a Assembleia Nacional e a Câmara Corporativa e a Lei $n^{\circ} 3$ / 74 que define , nas suas próprias palavras " a estrutura constitucional transitória que regerá a organização política do País até à entrada em vigor da nova Constituição Política da República Portuguesa".

A Lei $n^{\circ} 2 / 74$ apenas confirma que o novo poder se havia efectivamente esquecido da Câmara Corporativa. E de uma assentada corrige também a Lei $n^{\circ}$ 1/74. A Câmara Corporativa é extinta e a Assembleia Nacional seria também extinta e não apenas " dissolvida". Não há aqui nada de surpreendente. A extinção do órgão legislativo do anterior regime e do seu apêndice corporativo, e não a dissolução, não é uma simples questão de semântica. A " dissolução" sempre poderia ser entendida como uma solução transitória que manteria a validade jurídica do referido órgão ... à espera de novas eleições . A extinção não oferece dúvidas: desaparecem do novo ordenamento jurídico-constitucional a

${ }^{4} \mathrm{Na}$ realidade a consagração do feriado do 1 de Maio correspondia a uma velha aspiração do movimento sindical a que a oposição politica sempre deu lastro , mas pela proximidade da data com o golpe militar, poderia servir, como efectivamente serviu, como uma verdadeira legitimação popular da iniciativa militar. Daí que a consagração do feriado mais facilmente abriria caminhopese embora algum receio de eventuais desestabilizações provocadas por adeptos do antigo regime- a essa ansiada plebiscitação. 
Assembleia Nacional e a Câmara Corporativa como tal consagradas na Constituição de 1933 .

Mas as principais novidades resultam da leitura da Lei $n^{\circ} 3 / 74$. O que até então era escuro aos olhos do nosso candidato a historiador, amarrado , é certo, à unica fonte que consultou, a folha oficial, tornam-se agora menos turvas. Apesar de tudo, como veremos, ainda não inteiramente claras.

Desde logo tem acesso ao "Programa do Movimento das Forças Armadas Portuguesas", publicado em anexo à referida Lei e que " dela faz parte integrante" ( art. $1^{\circ} \mathrm{n}^{\circ} 1$ ). Aí constata que o mesmo prevê medidas imediatas e a curto prazo , que entre elas está a concentração do poder político do Estado na Junta de Salvação Nacional até à constituição de um Governo provisório civil . Que a J.S.N. destituirá o actual Presidente da República, o actual Governo e dissolverá a Assembleia Nacional e o Conselho do Estado e no prazo de 3 semanas escolherá entre os membros da Junta quem exercerá as funções de Presidente ( que manterá poderes semelhantes aos previstos "na actual Constituição") , que os restantes membros da Junta exercerão as várias chefias militares e " farão parte do Conselho do Estado" e que o novo Presidente nomeará o Governo provisório civil que será composto por personalidades representativas de grupos e correntes politicas e personalidades independentes que se identifiquem com o presente programa. Que o periodo de excepção se manterá até que estejam eleitos o Presidente da República e a Assembleia Legislativa, que resultarão da nova Constituição aprovada em Assembleia Constituinte eleita por sufrágio universal, directo e secreto e cuja convocação deverá ser realizada no prazo de doze meses. No Programa acentua-se ainda que entre as prioridades imediatas está a dissolução ou extinção das estruturas mais emblemáticas do antigo regime, como a DGS, a Legião Portuguesa, as organizações de juventude e ainda a amnistia dos presos politicos, a reintegração dos servidores do Estado afastados por motivos políticos, a abolição da censura e exame prévio, a previsão de uma comissão "ad hoc" para controle da imprensa, rádio, televisão, teatro e cinema que se manterá em funções até à publicação das novas leis de imprensa, rádio e televisão, teatro e cinema " pelo futuro Governo Provisório", medidas para reorganização e saneamento das forças armadas e militarizadas ( GNR, PSP , GF), controle das fronteiras e controle e combate quer das operações económicas e financeiras com o estrangeiro quer da corrupção e especulação.

Mas o Programa vai mais longe. Embora considerando que " as grandes reformas de fundo" só poderão ser adoptadas pela futura Assembleia Nacional Constituinte comina ao Governo provisório um amplo catálogo de medidas a "promover imediatamente": a) aplicação de medidas que garantam o exercício formal da acção do Governo e as condições de carácter material, económico, social e cultural que garantam a liberdade politica dos portugueses; ; b) liberdade de reunião e associação; c) criação de associações políticas possiveis embriões de partidos políticos ; d) promulgação de nova lei de imprensa, rádio, televisão, teatro e cinema; e) medidas para assegurar a independência do poder judicial; f) lançamento dos fundamentos de uma nova política económica posta ao serviço das camadas da população mais desfavorecida tendo como objectivo imediato a luta contra a inflação e alta excessiva do custo de vida o que " implica uma estratégia anti-monopolista"; g) uma nova política social que em todos os domínios terá essencialmente como objectivo a defesa dos interesses das classes trabalhadoras e o aumento progressivo e acelerado da qualidade de 
vida de todos os portugueses; h) em sede de politica externa impunha -se ao Governo Provisório a defesa dos princípios da independência e igualdade entre os Estados, da não ingerência nos assuntos internos dos outros países e da defesa da paz, alargando e diversificando relações internacionais com base na amizade e cooperação.

Por aqui se constatará que o movimento militar tem um ideário político , económico e social profundamente original na história pátria e que esse ideário é claramente progressista ( estratégia anti-monopolista e defesa dos interesses das classes trabalhadoras)

A esta luz o nosso candidato a historiador começa a confrontar as medidas legislativas da Junta de Salvação Nacional nos seus primeiros 20 dias - que antes resumimos - com o Programa do MFA e constatará que, no essencial , existe concordância.

O que não é ainda clara é a autoria do Programa do MFA. Isto porque no Diário do Governo o referido programa surge com a assinatura do Presidente da Junta de Salvação Nacional, António de Spínola. Para resolver este enigma terá de ler então com atenção a Lei $n^{\circ} 3 / 74$. Por aí constatará o seguinte :

a) que o "Programa do Movimento das Forças Armadas", elaborado pelo MFA, é um verdadeiro Acto Constitucional do Estado português ${ }^{5}$;

b) que a Junta de Salvação Nacional é composta por sete militares que " para o efeito receberam mandato do Movimento das Forças Armadas" ( $\operatorname{art.} 9^{\circ} \mathrm{n}^{\circ} 1$ ) ;

c) que o Movimento das Forças Armadas designa, na nova estrutura constitucional provisória, sete representantes das Forças Armadas que integrarão o futuro Conselho do Estado, órgão este que, entre outras funções, passará a exercer poderes constituintes ;

Para além disto é também muito claro o verdadeiro destino da Constituição de 1933. Um excesso de escrúpulo jurídico, parece ter prevalecido. Ou, talvez, um pavor ao vazio jurídico muito comum entre os juristas( que terão assessorado, neste aspecto, os militares). Manteve-se ela transitoriamente em vigor em tudo o que não contrariasse os principios expressos no "Programa do Movimento das Forças Armadas". Contudo, haverá que reconhecer que tal solução já decorria, pelo menos de forma pontual, do próprio Programa do MFA quando este, ao estipular acerca dos poderes do Presidente da República a emergir da Junta de Salvação Nacional ( ponto B-1) definia que " este manterá poderes semelhantes aos previstos na actual Constituição" ( a de 1933, é claro). Aliás, nesse aspecto a Lei $\mathrm{n}^{\circ} 1 / 74$, como vimos, havia ido mais longe. Certamente confortada com esta cláusula do Programa do MFA, estipulou que a Junta de Salvação Nacional concentraria os poderes do Presidente da República, do Presidente do Conselho dos Ministros, dos Secretários e Subsecretários de Estado, da Assembleia Nacional e do Conselho de Estado. Poderes esses que decorriam da Constituição de 1933 , como ninguém contestará .

5 Vide Jorge Miranda, A Constituição de 1976. Formação, Estrutura e Princípios Fundamentais, Lisboa, Livraria Petrony 1978, p. 42 
Lida a Lei $\mathrm{n}^{\circ} 3 / 74$ o nosso historiador começa realmente a ver mais claro. Uma nova ordem jurídica constitucional, impulsionada por um movimento militar, com uma fase inicial de concentração de poderes num directório militar, designado por Junta de Salvação Nacional, que leva a cabo, rapidamente, a destruição e eliminação da ordem jurídica e política do antigo regime e cujo documento inspirador, o Programa do MFA se torna a nova Constituição transitória .

Aí verificará que passam a ser orgãos de soberania, para além da futura Assembleia Constituinte a eleger ${ }^{6}$, o Presidente da República escolhido de entre os membros da Junta de Salvação Nacional, esta própria , o Conselho de Estado ( composto pelos membros da JSN, nove cidadãos ( civis ou militares) escolhidos pelo Presidente da República e nove militares escolhidos pelo MFA), o Governo Provisório cujo Primeiro Ministro e Ministros são escolhidos pelo Presidente da República e os Tribunais.

Se continuar a ler o Diário do Governo poderá, na edição de 15 de Maio, saber da orgânica do Governo Provisório e das suas principais linhas de actuação ( um verdadeiro programa do Governo, em obediência aos princípios do Programa do MFA) , o nome do primeiro Primeiro-Ministro do pós 25 de Abril , o Doutor Adelino da Palma Carlos, dos Ministros e dos Secretário de Estado.

Mas a verdade é que num ponto porém, permanecerá obscuro para o nosso historiador: quem são os membros da Junta de Salvação Nacional ?

Para o saber tem de investigar outras fontes. Nada melhor do que a imprensa da época.

\section{A VERTIGEM ( E OS EQUÍVOCOS) DA REVOLUÇÃo ATRAVÉS DA IMPRENSA : DOIS PROGRAMAS DO MFA?}

Hoje em dia não faltam fontes para o estudo do 25 de Abril, seus antecedentes e todo o período transitório que vai até à entrada em funcionamento dos órgãos de soberania previstos na nova Constituição .Não faltam fontes, é verdade, mas a riqueza da revolução, com tudo o que tem de imprevisto, pitoresco e marginal só pode ser dada pela imprensa. À data, Portugal tinha uma bem preparada e sobretudo muito lida imprensa que havia resistido com sucesso à censura prévia. Muitos e bons jornalistas forjados nas tarimbas das reportagens povoavam os diários e semanários do País que no seu conjunto imprimiam diariamente cerca de 500.000 exemplares $^{7}$. Existiam em

\footnotetext{
6 Aspectos de não somenos importância e que constituirá fundamento jurídico para que o PS, PPD e CDS aproveitassem a Assembleia Constituinte, sobretudo no período de antes da ordem do dia, como instrumento de verdadeira fiscalização e crítica quer da actuação do Governo Provisório quer dos restantes órgãos civis e militares .

7 A verdadeira circulação dos jornais e revistas à data do 25 de Abril carece de fonte rigorosas. Acácio Barradas refere que nos anos 60 e 70 o Diário Popular " era um jornal com uma grande influência vendia cento e tal mil exemplares por dia ..." vide Jornalismo \& Jornalistas Out/ Dez. 2008 p. 63. Francisco Pinto Balsemão refere que o Diário Popular chegou a ultrapassar nos anos 70 o DN " Na casa dos 130 mil" e " havia O Século a vender 80 ou 90 mil, O Diário de Lisboa , A Capital o os jornais do Porto que eram bons negócios e vendiam" in Expresso, Revista Especial comemorativa da edição $n^{\circ} 2000(26 / 2 / 2011)$. Ver também Fernando Correia e Carla Baptista, Memórias vivas do Jornalismo, Lisboa, Caminho, 2009, pp.14-15
} 
Lisboa 5 diários matutinos ( Diário de Notícias, O Século, A Época, Jornal do Comércio e Novidades) e 4 vespertinos ( Diário Popular, Diário de Lisboa, A Capital e República), O Porto, por seu lado, tinha 3 jornais diários ( O Primeiro de Janeiro, Jornal de Notícias e O Comércio do Porto). Os semanários viviam também um momento de pujança. O Expresso tinha pouco mais de um ano de vidaapresentando-se como um semanário inovador para a realidade portuguesa à imagem do "Observer" britânico - e as revistas de grande informação , muitas delas associadas aos grupos económicos que editavam os diários, multiplicavamse ( O Século Ilustrado, Flama, Vida Mundial, Observador, entre outras) .

A leitura dos jornais, que no dia $25^{8}$ e 26 chegaram a fazer 3 e 4 edições cada uma delas actualizando a anterior, dar-lhe- á uma perspectiva muito mais viva do ritmo dos acontecimentos. Verificará inclusive que o tempo do Diário do Governo nada teve que ver com o tempo real.

O nosso improvisado historiador ao compulsar as várias edições do dia 25 constará que o movimento militar começou por suscitar dúvidas no seu escopo político : seria um movimento de Direita ou de Esquerda ? E essas mesmas edições também transmitem a indefinição quanto ao sucesso golpe militar .

$\mathrm{Na}$ verdade, se é certo que as últimas tiragens dos vespertinos dão a conhecer a confirmação da vitória do movimento militar das forças armadas e da destituição do Presidente do Conselho de Ministros Marcello Caetano na presença do General António de Spínola ${ }^{9}$, o que de algum modo afastava a ideia de um golpe de direita, só no dia seguinte é possível conhecer com mais rigor o sentido político e jurídico-constitucional do Movimento. Isso decorre de dois documentos: a declaração lida por Spínola na RTP na madrugada do dia 26 de Abril e o Programa do MFA. Ambos são publicados na Imprensa desse dia, sendo que o segundo é lido pelo Major Vitor Alves aos jornalistas na conferência de imprensa que na manhã do dia 26 é dada por António de Spínola no quartel da Pontinha. Ambos os textos confirmam a intenção inequivocamente democratizadora do Movimento militar, o compromisso civilista e a vinculação à elaboração de uma nova Constituição para Portugal .

A versão que os jornais publicam do Programa do MFA não é exatamente igual à que veio a ser publicada 20 dias depois no Diário do Governo e de que demos conta antes. Mas as alterações são formais e de pormenor e não alteram nada de substancial. Num caso porém o texto do Programa que surge impresso é substancialmente diverso do publicada na folha oficial. É o caso do jornal República de 26 de Abril que publica uma versão do programa com a expressa

\footnotetext{
8 As primeira edições dos jornais dão conta da movimentação militar, sem contudo conseguirem identificar claramente os propósitos do movimento, sendo certo que a probabilidade de um golpe militar de direita levado a cabo pelo General Kaulza de Arriaga não era de descartar . Kaulza , recorde-se , 12 dias antes do 25 de Abril havia enviado uma carta ao Presidente Américo Tomás quase que exigindo a necessidade em demitir Marcelo Caetanto " antes de cair no abismo", vide Josep Sanchez Cervelló, A Revolução Portuguesa e a sua influência na Transição Espanhola ( 1961-1976), Libsoa, Assirio \& Alvim, 1993, p. 174
}

9 Diário Popular, 25/4/74, $4^{\text {a }}$ tiragem, capa 
referência à autodeterminação das Colónias, ausente da versão oficial ${ }^{10}$. Para o nosso observador o pormenor não deixará de intrigar. Mas aí a razão de ser só se tornará clara quando acompanharmos o processo de redação e alteração do Programa a que daremos atenção no capítulo seguinte.

E, é claro, ficará também a saber o que pelo Diário de Governo nunca se saberá, que os membros da JSN são sete, três do Exército ( Spínola, Costa Gomes e Silvino Silvério Marques) dois da Marinha ( Pinheiro de Azevedo e Rosa Coutinho) e dois da Força Aérea( Diogo Neto e Galvão de Melo), que entre eles escolheram como Presidente António de Spínola .

Da leitura dos jornais dos dias subsequentes o nosso leitor ficará a saber que o país entrou num verdadeiro turbilhão social e económico, de que as páginas do Diário do Governo só muito abstractamente reflectem( mas a verdade é que não deixam de o reflectir) ${ }^{11}$. Os avatares da libertação dos presos políticos de Caxias e Peniche ${ }^{12}$, as refregas junto à sede da DGS em Lisboa, de que resultaram nos 4 únicos mortos directamente imputados ao 25 de Abril, a particularidade de ainda se ter tentado realizar uma sessão da Assembleia Nacional no dia 26, que naturalmente foi cancelada ${ }^{13}$, as primeiras reportagens sobre os segredos do 25 de Abril ${ }^{14}$, os primeiros comunicados do PS e do PCP15, o regresso de Álvaro Cunhal e Mário Soares, o anúncio de novos partidos políticos e claro, após a extraordinária manifestação do 1 de Maio, as revindicações de toda a ordem e natureza desde a exigência de saneamentos dos " elementos ligados ao regime derrubado"16, às reivindicações de salários e regalias laborais, de permeio com greves, especulação com bens essenciais de consumo, corrida aos bancos, fuga de capitais e restrições no abastecimento de combustiveis. E até, discretamente, em página interior, a notícia do falecimento de quem supostamente não suportou tanta liberdade :" Morreu o Pedro Oom fulminado por um ataque cardiaco. Não resistiu à emoção da hora. Tinha 47 anos, um pouco menos que o regime deposto. Anos todos de humilhação"17

Saberá também o nosso candidato a historiador que os primeiros diplomas da Junta de Salvação Nacional foram enviados para a Imprensa Nacional no dia

10 A versão conseguida pelo jornalista Álvaro Guerra antes de ter eclodido a insurreição armada não era ainda a definitiva, vide Avelino Rodrigues, Cesário Borga e Mário Cardoso, $O$ Movimento das Capitães e o 25 de Abril , 5 edição, Lisboa, 2014,p. 26

11 Vide para um registo diário dos acontecimentos politicos, económicos e sociais ocorridos na época, Luís Violante e João Morais, Contribuição para uma Cronologia dos factos económicos e sociais e em portugal, 1926-1985, Lisboa, Livros Horizonte, 1986, p. 241 e ss

12 Diário Popular, 26/4/74 p. 20; Diário Popular, 27/4/74 p. 3

13 Diário Popular, 26/4/74, p. 24

14 Diário Popular, 26/4/74,p. 10; Diário Popular, 27/4/74,p. 21

15 Diário Popular 29/4/74 pp. 7 e 21

16 Diário Popular, 29/4/74, p. 8

17 Cfr. A República , 27/4/74 p. 24. Pedro Omm foi um dos escritores que impulsionaram , com Mário Cesariny, Cruzeiro Seixas, António Maria Lisboa e muitos outros o movimento surrealista em Portugal. 
O “PROGRAMA DO MOVIMENTO DAS FORÇAS ARMADAS: O SINGULAR...

29 de Abril...18 embora, tenham sido publicados em edições com a data de 25 e 26 de Abril!

Conclusão de toda esta história : quem quer ser historiador e saber do que verdadeiramente aconteceu não pode fiar-se no Diário do Governo...

Mas a verdade é que também não pode confiar na imprensa !

Por exemplo e como vimos já, no que diz respeito ao Programa do MFA objecto deste texto - a versão que o nosso candidato a historiador terá lido no velho e respeitável "República" - o mais antigo e prestigiado dos jornais de oposição ao Estado Novo - não coincide com aquela que o Diário do Governo do dia 14 de Maio imprimirá.

\section{AS VERDADEIRAS ORIGENS, TRANSFORMAÇÃO E DESTINO DO PROGRAMA DO MFA: A "LETRA", O " NÚCLEO FUNDAMENTAL " , OS "PRINCÍPIOS" E O "ESPÍRITO"}

Chegados a este ponto é possivel hoje reconstituir as origens, a transformação e o destino do Programa do MFA. No essencial esse trajecto está hoje bem identificado, embora persistam alguns pontos menos claros em torno dos quais os historiadores hesitam .

O Movimento dos capitães começou por ser uma resposta de natureza essencialmente jurídico-laboral dos oficiais do quadro oriundos da Academia Militar contra o Decreto-Lei n 353 de 13/7 e o Decreto Lei $n^{\circ} 409$ de 20/8 ambos de 1973. A movimentação que começou a ganhar forma em Setembro de 1973 foi registando cada vez mas adesões e estruturou-se territorialmente ( incluindo logicamente os militares nas Colónias). Mas manteve sempre uma estrutura centralizada em Lisboa, a Comissão Coordenadora. Na Assembleia dos oficiais de 24 de Novembro de 1973 realizada em São Pedro do Estoril em que participam 45 oficiais das principais unidades do Exército do país, são consideradas três alternativas para a futura actuação do movimento : a) conquistar o poder e entregá-lo a uma Junta Militar para democratizar o país; b) dar oportunidade ao Governo de se legitimar perante a Nação através de eleições livres, fiscalizadas pelo Exército e antecedidas de um referendo sobre a política ultramarina; c) utilizar as reivindicações exclusivamente militares para recuperar o prestígio do exército e pressionar o Governo ${ }^{19}$. Para discutir estas propostas nova reunião se realizou desta feita em Óbidos no dia 1 de Dezembro em que participaram 86 oficiais em representação de mais de 200.

Tendo vencido a terceira opção, com pouca diferença da primeira, foi criada uma Comissão Coordenadora e dentro dela uma Comissão Executiva composta por Otelo Saraiva de Carvalho, Vitor Alves e Vasco Lourenço. O facto destes últimos serem partidários da tese do golpe militar e, sobretudo, a progressiva degradação político-militar do país, levaram a Comissão Coordenadora a avançar na linha do golpe militar e a afastar os restantes cenários. Contudo, é só após a

18 Em rigor refere-se que a Lei $\mathrm{n}^{\circ} 1 / 74$ e os diplomas relativos à dissolução da ANP, o da amnistia dos crimes políticos, o da criação de delegados da JSN no ministérios civis, " são publicados esta manhã" Diário Popular, 29/4/74, p. 9

19 Vide Sanchez Cervelló, op.cit. p. 160 
publicação do livro de António de Spínola " Portugal e o Futuro" no qual se expunha o pensamento do General em relação aos problemas do país ( propondo como meio para pôr fim à Guerra Colonial uma solução federal integrando as Colónias) que a Comissão Coordenadora do Movimento dos capitães , confrontada entre assumir o projecto de Spinola ou fazerem o seu, ${ }^{20}$ decidem, a 25 de Fevereiro, nos arredores de Lisboa, elaborar o seu próprio Programa. Um primeiro documento de síntese, que recebeu as sugestões dos vários representantes do Movimento , elaborado pelo Exército intitulado " O Movimento, as Forças Armadas e a Nação" foi discutido pela Comissão Coordenadora a 3 de Março. Este documento não resistiu, contudo, à aproximação dos preparativos militares, já após a frustrada tentativa militar de 16 de Março e ao envolvimento complexo e não linear de Spínola e Costa Gomes. A Direcção do Movimento encarregou então Melo Antunes ${ }^{21}{ }^{22}$ de ultimar um programa político e Otelo a solução militar. O programa foi colocado à consideração de Spínola e Costa Gomes, tendo o primeiro introduzido várias alterações ${ }^{23}$. Juntamente com o Programa é elaborado um Protocolo do Movimento das Forças Armadas e a Junta 24, que seria uma espécie de compromisso entre o MFA e futura Junta de Generais pela qual esta se comprometia a cumprir o definido no Programa, protocolo esse que nunca veio a ser assinado pelos futuros membros da Junta de Salvação Nacional ${ }^{25}$.

Finalmente quanto tudo parecia definido, na própria noite de 25 de Abril , após a rendição de Marcello Caetano , e os membros da Junta de Salvação Nacional chegam à Pontinha( com excepção do General Diogo Neto que estava em

\footnotetext{
20 Vide idem, ibidem, p. 168
}

21 Sabemos hoje que a redação do Programa do MFA foi o produto de várias mãos. Uma primeira versão encarregue pela Comissão Coordenadora do MFA a José Maria Moreira Azevedo, depois reformulada por Melo Antunes, Costa Brás e Sousa e Castro, mais tarde o mesmo Melo Antunes ficaria encarregue de redigir uma versão definitiva no que terá tido a colaboração de Vitor Alves, Franco Charais, Costa Brás e Vasco Goncalves e finalmente tudo confluiu em várias alterações sugeridas por António de Spínola e Costa Gomes , algumas delas já no próprio dia 25 de Abril Vide Maria Inácia Rezola, 25 de Abril . Os mitos de uma revolução, Lisboa, Esfera dos Livros , 2007, pp. 47-51

22 Para outros Autores e se bem que o essencial da redacção tenha pertencido a Melo Antunes , alguns outros militares colaboraram na redacção, como Martins Guerreiro, Vitor Alves, Franco Charais, Costa Brás ou Vasco Goncalves . Vide Josep Cervelló, op.cit. p. 177

23 " As propostas de Spínola segundo Vítor Alves foram um tanto controversas: " estivemos muito tempo a emendar e a modificar. Ele foi cedendo o menos possível dentro da sua ideia. De facto não era aquilo que ele queria", vide Josep Cervelló, op.cit. p. 175. A primeira redacção do Programa onde se fala em Directório Militar e não Junta de Salvação Militar sofre com algumas as alterações por parte de Spinola, designadamente este rejeita a abolição da censura, o controlo da RTP e Emissora Nacional ou a liberdade sindical, por exemplo, mas mantém nesta versão o reconhecimento do direito à autodeterminação por parte dos povos das Colónias vide Avelino Rodrigues, Cesario Borga e Mário Cardoso, op.cit. pp. 329-333

24 Ver o texto do Protocolo e um ante-projecto em Maria José Toscar Santiago ,O 25 de Abril e o Conselho de Estado, A questão das Actas, Lisboa, Colibri, 2012, pp. 237 e 246-249. Não deixa de ser curioso notar que o Protocolo não definia uma nova politica ultramarina, sendo até particularmenre enfático quanto à necessidade da " Nação", no quadro do novo regime , se pronunciar após eleições. Dizia mesmo " O MFA não aceita por qualquer forma que nos próximos doze meses seja resolvido o problema do Ultramar". No fundo isso traduzia o debate e a indefinição no próprio seio do MFA a que a concepção federalista de Spinola agravaria ainda mais .

25 Vide Josep Cervelló, op.cit. p. 175 
Moçambique e que só chegará a 28 de Abril), - antes de se dirigirem à RTP para lerem a sua Proclamação ao País ${ }^{26}$ - decidem reapreciar o Programa do MFA no que se confrontam com a Comissão Coordenadora do MFA 27. Apesar da resistência desta última, a verdade é que em dois pontos o programa é alterado: na manutenção da DGS nas Colónias ,que deverá permanecer ainda que com outra designação, em razão do estado de guerra e das vantagens em manter um serviço de informação a funcionar - e só isso explica a esdrúxula solução contida do Dec.Lei $\mathrm{n}^{\circ} 171 / 74$ de 25/4- alteração proposta por Costa Gomes ${ }^{28}$ e na exclusão do controvertido ponto relativo à autodeterminação dos povos dos territórios ultramarinos.

Dois outros pontos menores resultaram desse compromisso : a entrega da direcção politica das províncias ultramarinas aos secretários gerais, em vez dos comandantes chefes e a exclusão dos condenados por delitos comuns da amnistia como constava da versão inicial ${ }^{29}$.

É portanto este o texto - resultante dos " acordos da Pontinha" 30 que acaba publicado em anexo à Lei Constitucional no $3 / 74$ de 14 de Maio.

O Programa do MFA só por si e como alguns notam " faz a originalidade da revolução" 31. Do ponto de vista comparativo raros são os golpes militares em que os seus autores se mostram em condições de definir orientações imediatas e a curto prazo que permitam clarificar e consolidar os objectivos da intervenção. Aliás como bem nota Kenneth Maxwell, " enquanto os correspondentes e diplomatas estrangeiros se embrenhavam laboriosamente através da sintaxe barroca de "Portugal e o Futuro" de Spínola em busca de alguma pista sobre o que poderia acontecer a seguir em Lisboa o programa do movimento era pouco discutido apesar do facto de rapidamente ter sido promulgado como constituição transitória da República Portuguesa" 32 .

Curiosamente o Programa do MFA vai quase sempre ser invocado nos debates politico-militares da fase transitória, em regra para fundamentar as alterações propostas no devir político militar. Isso quer na numerosa legislação transitória, quer nas discussões da Assembleia Constituinte, quer no debate político-partidário mais amplo . É verdade que alguns sustentam que "o

26 Proclamação que também não coincide com aquela que antes do 25 de Abril tinha sido preparada pela Comissão Coordenadora do MFA e entregue aos Generais Spínola e Costa Gomes , vide Maria José Tiscar Santiago, op.cit. p. 48

27 Nessa discussão conforme recorda Vitor Alves, tiveram papel destacado Charais e Vitor Crespo, que passaram o tempo todo a dizer-lhe : "Está bem, os tanques estão na rua. Vamos pôlos outra vez em marcha até esclarecermos o assunto " ,vide Josep Cervelló, op.cit. p. 183

28 A manutenção da DGS no Ultramar, alegando-se ser fundamental a sua permanência para o esforço de guerra, resulta de uma objecção de Costa Gomes ao Programa inicial do MFA , em reunião realizada na Pontinha com a Comissão Coordenadora do MFA, na noite do 25 de Abril a escassas horas da apresentação da J.S.N. ao país através da televisão vide Maria Inácia Rezola, op.cit. p. 60

29 Vide Maria José Tiscar Santiago, op.cit.p. 46

30 Vide idem, ibidem, p. 48

31 Vide Avelino Rodrigues, Cesário Borga e Mário Cardoso,op.cit. p. 27

32 Vide Kenneth Maxwell, A Construção da democracia em Portugal, Lisboa, Presença, 1999, p. 83 
Programa pouco mais terá sido de que uma Constituição nominal, quando não uma Constituição semântica, no sentido de K. Loewenstein " 33 . Mas mesmo esses acabam por reconhecer que o Programa nunca foi repudiado, perduraria durante a Assembleia Constituinte e " acabaria por ser expressamente mencionado no art. $273^{\circ} \mathrm{n}^{\circ} 2$ da Constituição ! " 34 .

O programa vai ser invocado como verdadeira Lei Constitucional, desde logo pelos partidos politicos, para reagir a favor ou contra as decisões políticas e legislativas do Governo Provisório. Na verdade, como se verá, " todas as instâncias jurídicas e governativas se remetem como fonte legitimadora para a aprovação de novas leis e a publicação de novos decretos" 35

Do complexo processo que se vive até à aprovação da Constituição a 2 de Abril de 1976 há um conjunto de acontecimentos que os historiadores têm referenciado como constituindo momentos de clivagem decisivos na evolução político-militar. Alguns delas, aliás bem conhecidos e estudados, são os seguintes

a) Crise do Governo I Governo Provisório ( Palma Carlos)( 9 de Julho de 1974);

b) Lei da Descolonização ( 24 de Julho de 1974);

c) Tentativa spinolista do 28 de Setembro de 1974;

d) Criação do Conselho Superior do MFA ( 6 de Dezembro de 1974): institucionalização do MFA ;

e) Unicidade sindical vs. Liberdade Sindical ( Janeiro de 1975)

f) Tentativa de golpe militar do 11 de Março de 1975: institucionalização do Conselho da Revolução , nacionalizações ;

g) I Pacto MFA/ Partidos e a questão das eleições para a Constituinte ( 11 de Abril de 1975) ;

h) as eleições para a Assembleia Constituinte( 25 de Abril de 1975)

i) Caso "República" ( Maio de 1975);

j) Plano de Acção Política ( 21 de Junho 1975)

k) O Documento dos Nove ( 7 de Agosto 1975)

1)A tentativa de golpe militar de 25 de Novembro

m) O II Pacto MFA -Partidos

Este treze acontecimentos político- militares são significativos não tanto por traduzirem momentos de aproximação ou de distância em relação ao Programa do MFA, mas sobretudo por marcarem o percurso do afrontamento entre várias lógicas pós 25 de Abri : um primeiro momento de clivagem entre a urgência da institucionalização do MFA e a urgência da ratificação popular de um 25 de Abril " civilista" e "spinolista", que conduz ao afastamento primeiro de Palma Carlos e depois do próprio Spínola e um segundo momento de afrontamento entre o aprofundamento de um MFA institucionalizado com um mandato revolucionário e socialista e a defesa da legitimidade democrática resultante das eleições para a Constituinte como um projecto de democracia pluripartídária e pluralista, que desemboca no triunfo desta última perspectiva

\footnotetext{
33 Vide Jorge Miranda, op.cit. p. 43

34 Vide Jorge Miranda, op.cit. p. 44

35 Vide Maria José Tiscar Santiago, op.cit.. p. 48
} 
como corolário do 25 de Novembro. Claro que é sempre possivel condensar a multiplicidade dos assinalados 13 momentos em três fases políticas : do 25 de Abril de 1974 a 11 de Março de 1975, do 11 de Março ao 25 de Novembro de 1975 e desta data até á entrada em vigor da Constituição e dos órgãos constitucionais definitivos ${ }^{36}$. Mas essa arrumação empobrece a análise e não permite evidenciar a posição em que o Programa do MFA, objecto deste estudo, acabou por ser colocado.

Vejamos pois, ainda que por referência a alguns momentos simbólicos, de que forma os vários intervenientes politicos e militares nestes acontecimentos se posicionam por referência ao Programa do MFA.

O primeiro desses momentos simbólicos é a crise do I Governo Provisório.

A crise Palma Carlos foi o primeiro conflito político que abanou o pós 25 de Abril de forma séria, levando à queda do I Governo Provisório e na sua recomposição ao afastamento do então Primeiro Ministro Palma Carlos e do Ministro sem pasta Francisco Sá Carneiro, entre outros. O propósito de Palma Carlos, com ou sem o apoio de Spínola, era criar condições para um referendo destinado à aprovação de um projecto de Constituição Provisória que se manteria em vigor, caso fosse aprovada, até à entrada em vigor da Constituição definitivamente ratificada pela Assembleia Constituinte; simultaneamente com o referendo os portugueses elegeriam por sufrágio universal e directo um Presidente da República.

$\mathrm{Na}$ exposição de motivos que Palma Carlos elaborou tendo em vista convencer os membros do Conselho de Estado a apoiar a sua solução, este é claro ao referir que o Programa do MFA " tendo adquirido valor constitucional " 37 , se mostra "ultrapassado" pelo Programa do Governo Provisório civil, pelo brotar dos partidos e pelo início das negociações com o PAIGC e a Frelimo e ainda é " inadequado ou insuficiente" para se vencer a conjuntura económica e social ${ }^{38}$. Ou seja, Palma Carlos é taxativo quanto á necessidade da desadequação do Programa do MFA ao seu propósito e da necessidade na derrogação do mesmo e da sua substituição por uma outra estrutura constitucional provisória.

Contudo a irradiação do Programa do MFA como fonte legitimadora do 25 de Abril não deixa de estar presente na crise Palma Carlos, quando este entende que o seu projecto é o que apesar de tudo mantém a " fidelidade ao núcleo essencial do Programa do MFA " . Qual seja esse núcleo essencial parece claro ser a da " mais rápida caminhada para a institucionalização da democracia" . E de certo modo Palma Carlos ao manter no seu projecto a convocação de uma Assembleia Constituinte para aprovar a Constituição definitiva parece entender que esse compromisso é também um dos que se inclui no " núcleo essencial do programa do MFA". Aliás o seu projecto de consulta popular na parte da " intervenção directa do povo no processo político" deixa claro a manutenção da vigência do Programa do MFA que assim se manteria aplicável pelo menos na parte da eleição da Assembleia Constituinte.

36 Vide Jorge Miranda, Manual de Direito Constitucional, Tomo I,7 ${ }^{\mathrm{a}}$ ed. Coimbra, Coimbra Editora, 2003 , p. 345

37 Vide Jorge Miranda, Fontes e Trabalhos Preparatórios da Constituição, vol. II, Lisboa, INCM, 1978. p. 1154

38 Vide idem, ibidem, p. 1158 
A ideia de um " núcleo essencial do Programa" argumentada por Palma Carlos irá ser recuperada em momentos posteriores quando se ensaia uma nova linguagem política que remete para os principios do Programa ou para o espírito do Programa.

Na verdade da letra do Programa passa-se para os "princípios do Programa do MFA" e deste para o "espírito do Programa do MFA" ( ver a Lei $\mathrm{n}^{\circ}$ 17/75 de 26/12, que refere no preâmbulo o espírito do Programa do MFA) . Esta progressiva diluição foi uma estratégia destinada a tornar menos denso o texto do Programa do MFA. Uma menor densidade do texto permite uma maior acomodação a todas as interpretações, mesmo aquelas que manifestamente não são compativeis com a letra . E não se pense que essa estratégia partiu apenas dos que defenderam a dada altura a prevalência da legitimidade revolucionária próxima do PCP e da extrema esquerda. Também os grupos político-militares próximos do PS , do PPD e do CDS utilizaram idêntica estratégia.

A própria Comissão Coordenadora do MFA veio a público pronunciar-se várias vezes sobre o sentido e alcance do Programa. No fim de 1974 e pela voz de Franco Charais a Comissão dizia que Programa " ratificado" pelo povo a 1 de Maio, não é um documento preenchido com conceitos e proposições rígidas que pretende traçar a régua e esquadro, a orientação política económica e social da nação" 39 . E acrescenta " como programa de um movimento não poderá deixar de ser dinâmico procurando a solução dos problemas surgidos pela aplicação constantemente ponderada, dos seus princípios orientadores aos dados reais da situações a cada momento"" O programa só poderá considerar-se ultrapassado ou ambiguo apenas por quem dele faça uma leitura formal, sem atender ao seu espírito, espírito este que resulta claro numa leitura atenta e sem preconceitos..." - E exemplifica com a aprovação da Lei $n^{\circ} 7 / 74$ quanto ao reconhecimento do direito à autodeterminação das colónias, reconhecendo que formalmente esse direito não constava do Programa, mas que tal corolário não pode deixar de resultar do seu espírito.

Também Vitor Alves, um dos elementos da Comissão Coordenadora do MFA e como tal ministro sem pasta no IV Governo provisório, e que mais tarde será um dos nove no Documento com o mesmo nome, em entrevista dada a 22/2/75 interrogado sobre o receio de alguns de que " os militares não regressem aos quartéis" reconhece que " quem ler o Programa do MFA verifica facilmente que a ideia inicial era o regresso aos quartéis logo após a eleição do futuro Presidente da República e da Assembleia Legislativa. A forma como a vida política económica e social se desenvolveu ao longo destes nove meses veio a provar a impossibilidade desse "desideratum". Assim é forçoso que o MFA acompanhe o processo para além do prazo inicialmente previsto"40

Outros dos momentos simbólicos é o confronto acerca da liberdade/unicidade sindical.

Nesse intenso debate que constituiu um dos primeiros momentos de ruptura entre, de um lado o PS e o PPD e do outro o PCP e as restantes forças de

\footnotetext{
39 Vide idem, ibidem,p. 1169

40 Cfr. O Século Ilustrado, 22/2/75 p. 9
} 
esquerda, a defesa do princípio da liberdade sindical, que no caso se traduzia no repúdio de uma solução legal que impusesse a existência de uma única central sindical, no caso a CGTP-Intersindical ( controlada pelo PCP), veio a ser sustentada pelo PS e pelo PPD. Este último, pela voz de Sá Carneiro , é enfático ao sustentar que "O programa do MFA impõe a nossa ver o princípio da liberdade sindical " 41 . Para o PPD a leitura que era feita do Programa do MFA recondu-lo a uma verdadeira lei fundamental do período transitório.

O terceiro momento simbólico corresponde à tentativa de institucionalização do MFA como instrumento de condução politica da " revolução socialista", no chamado Verão Quente de 1975.

Na verdade, a aceleração da revolução portuguesa que transformou o MFA num " Movimento de Libertação nacional" com o objectivo da " construção de uma sociedade socialista" obrigou a reinterpretação do Programa do MFA que agora é a base da construção dessa sociedade socialista. É o que se lê no ponto 1.5 do Programa de Acção Política do MFA aprovado pelo CR ( 19/6/75)

Esta invocação do Programa do MFA para sustentar uma estratégia de radicalização da situação económico e social é acompanhada pela comunicação social , na esmagadora maioria nas mãos do Estado, pela via da intervenção deste nas empresas proprietárias ( as nacionalizações de empresas, designadamente da banca e dos seguros determinou a passagem para o Estado das participações sociais dessas entidades nos jornais e revistas). Um exemplo entre muitos: a revista semanal Vida Mundial, detida pela Sociedade Nacional de Tipografia e que por sua vez havia passado maioritariamente para o controlo do Estado , dirigida pelo escritor Augusto Abelaira, sustentava a nacionalização da Sociedade Central de Cervejas, na lógica do ataque aos grandes monopólios " o que está contido no Programa do MFA"42

Curiosamente os documentos que procuram traduzir a passagem para uma linha politico-militar vanguardista, quer por impulso do PCP quer da extremaesquerda, como são os casos do Documento da Aliança Povo-MFA aprovada na Assembleia do MFA de 8/7/95 ou o Documento de autocrítica revolucionária do $\operatorname{COPCON}(13 / 8 / 75)$, não contêm qualquer referência expressa ao Programa do MFA .

Mas a involução desse processo, que corresponderá a um quarto e último momento simbólico, não deixa de se fazer invocando de novo o Programa do MFA.

É o caso do Documento dos $9(7 / 8 / 75)$ ao colocar o Programa do MFA como " elemento teórico da Revolução democrática" e ao conferir-lhe centralidade no ataque " à teoria leninista da vanguarda revolucionária" e " às novas formas de totalitarismo"43 . Em certo sentido pois o desenlace do 25 de Novembro que marcou a vitória dos militares moderados ( próximos do PS e do PPD) e recentrou a revolução na via democrática e pluralista foi realizado sob a égide do Programa do MFA.

\footnotetext{
41 Cfr. Povo Livre , 21/1/1975, pp. 8, 9 e 10

42 Cfr, Vida Mundial, 20/2/1975 , p. 19

43 Vide Jorge Miranda, Fontes e Trabalhos Preparatórios, cit. pp. 1198-1199
} 
É claro que estes acontecimentos têm óbvia implicação no quadro constitucional transitório, designadamente no destino e sentido das várias Leis Constitucionais, primeiro do Conselho de Estado e depois de 14 de Maio de 1975, do Conselho da Revolução.

\section{A REFLEXÃO HISTÓRICA E POLÍTICA SOBRE O PROGRAMA DO MFA : AS FORÇAS ARMADAS E O PODER POLÍTICO.}

A palavra agora aos historiadores. No quadro da geral desvalorização do valor fundador, constitucional e percursor do Programa do MFA, têm sido eles apesar de tudo a aprofundarem o tema e a escreverem algumas das mais interessantes páginas.

Uma das análises históricas mais interessantes e que não desvaloriza a importância do Programa do MFA é a de Medeiros Ferreira.

Segundo ele " do ponto de vista histórico o trânsito efectuado pelas forças armadas portuguesas entre o regime de ditadura derrubado a 25 de Abril de 1974 e a promulgação da Constituição a 25 de Abril de 1976 é, sem duvida notável e sem exemplo na história das passagens de regimes ditatoriais a regimes de democracia política". Segundo o historiador o Movimento das Forças Armadas foi uma " metamorfose da instituição militar para esta se insubordinar e derrubar o regime ditatorial e para gerir o complexo e convulsivo período seguinte, marcado pela descolonização e por um processo de agitação da sociedade portuguesa sem precedentes neste século. Digamos que a instituição militar "mobilizou" um corpo de intervenção especial político-militar" 44. " Efectuando uma distinção entre o Movimento dos Capitães e o MFA, assinala que o primeiro é responsável pela conspiração e pelo derrube da Ditadura enquanto que o segundo pelo "período de transição posterior que sempre se quis institucional, legal e constitucional" 45 . E conclui que "foi através do EMGFA que se procedeu à execução inicial do programa do MFA dentro dos cânones da disciplina própria à hierarquia militar ".

Colocando o problema de saber se existiu um pensamento estratégico por parte da instituição militar em todo o período pré constitucional, conclui afirmativamente, valorizando a intervenção da estrutura militar no cumprimento do Programa do MFA " como missão militar a cumprir" 46 como uma das notas originais do processo. " Para sobreviverem as Forças Armadas colocam a questão do regime político. O MFA apresenta desde logo o seu programa, como objectivo concreto e prioritário a atingir, a restauração da democracia. Pela primeira vez neste século uma revolução militar era acompanhada de uma opção de um certo regime político ${ }^{47}$ ora uma das características da condução do processo político desencadeado pelo MFA será a revelação de uma elite militar com capacidade de pensamento estratégico

44 Vide Medeiros Ferreira, História de Portugal ( José Matoso, dir.), Volume Oitavo, Lisboa , Círculo de Leitores, 1994, p. 224

45 Vide idem, ibidem, p. 225

46 Vide idem, ibidem, p. 227

47 Vide idem, ibidem, p. 231 
sobre a instituição militar e sobre a resolução dos grandes problemas nacionais. E essa elite, de uma forma geral, manter-se-á de acordo ao considerar o regime democrático e pluralista como o mais adequado à afirmação do Estado Português e à sobrevivência da própria instituição militar" 48. E conclui : " o segundo Pacto MFA -Partidos Políticos de Fevereiro de 1976 corresponde ao essencial da estratégia militar no campo politico após o derrube da Ditadura e até à revisão constitucional de 1982(...). Ora a intervenção das Forças Armadas ( por comparação com o I Pacto) " é atenuada, concentrada e sublimada na eleição directa de um militar para Presidente da República e ainda pelas atribuições do Conselho da Revolução como órgão de soberania transitório. Nesse segundo pacto a organização do poder político é atribuída fundamentalmente aos partidos, tendo a instituição militar garantido até à revisão constitucional de 1982 , a independência legislativa e administrativa através do Conselho da Revolução e dos Chefes de Estado Maior (...)" 4950

A verdade é que esse pensamento estratégico, como tal definido por Medeiros Ferreira, está ausente das anteriores rupturas constitucionais portuguesas do sec. XX.

Um apelo à memória das nossas anteriores rupturas constitucionais do sec. XX permitirá evidenciar a originalidade do 25 de Abril em muitos aspectos. Haverá certamente muitos pontos comuns com outras alterações políticas de fundo, levadas a cabo por militares ( ou mesmo por civis), nos secs. XIX e XX, mas a verdade é que nenhuma outra se pode comparar na preocupação constitucionalista, ou seja de definir um rumo ( ou um compromisso) que viesse desde logo e no imediato garantir ( ainda que transitória e provisoriamente) os Direitos Fundamentais da pessoa humana e a separação de poderes e a curto prazo transformar essas garantias em definitivas através da aprovação de uma Constituição democrática pela via de um processo constituinte de tipo democrático representativo . E quer queiramos ou não isso decorreu do Programa do MFA.

Nenhuma outra revolução ou golpe de Estado do sec.XIX e XX se aproximam - 5 de Outubro é o paradigma de uma revolução civil levada a cabo por militantes de um partido político , o Partido Republicano Português com o apoio de alguns militares, que transformam o seu Programa Político no Programa do Estado português. Eles próprios assumem o poder constituindo-se em Governo Provisório da República ( que legislará de forma intensa em ordem a cumprir os

48 Vide idem, ibidem, p. 231

49 Vide idem, ibidem, p. 231

50 Daí que tenhamos sempre defendido que o modelo de sistema de governo presente na versão originária da Constituição de 1976, anterior portanto à $1^{\text {a }}$ Revisão Constitucional, e como resultado do II Pacto MFA - Partidos se caracterizava por ser misto semipresidencial e directorial militar, e não apenas semipresidencial como a maioria da doutrina defende, justamente porque se verificava uma simbiose entre dois órgãos, Presidente da República e Assembleia da República com legitimidade democrática e um Conselho da Revolução com legitimidade revolucionária e amplas competências politicas, legislativas e regulamentares, das quais a de não menor relevo seria a da fiscalização da compatibilidade da normas jurídicas com a Constituição e a declaração da inconstitucionalidade com força obrigatória geral (, vide Ricardo Leite Pinto, José de Matos Correia e Fernando Seara, Ciência Politica e Direito Constitucional, vol . I ( $5^{\circ}$ edição) , 2013, pp. 351 
principais ditames do programa do Partido Republicano) e só mais tarde dando a conhecer a intenção da convocação de eleições para uma Assembleia Constituinte com poderes para aprovar uma nova Constituição. A situação do Governo Provisório da República que se traduz num directório político com concentração absoluta de poderes manter-se-á até à aprovação da Constituição quase um ano depois do 5 de Outubro de 1910.

O 28 de Maio de 1926 é um golpe militar clássico levado a cabo por altas patentes militares que tem como único ponto programático pôr fim ao monopólio do poder político do Partido Republicano. Não esboça a menor preocupação com a transição jurídico-constitucional, concentrando todos os poderes do Estado num Governo de cariz militar com alguns civis em pastas técnicas. Só mais tarde, já nos anos 30 e sobretudo com a consolidação de Salazar como ministro das Finanças o novo regime encontra a sua bússola ideológica e jurídico-constitucional.

Contudo esta opinião não é partilhada por todos . António José Telo, por exemplo, sustenta que o 25 de Abril foi um movimento original e diferente dos muitos golpes e contra-golpes que marcaram o regime republicano de 1910 e os primeiros anos da Ditadura Militar ${ }^{51}$. Contudo considera que o 25 de Abril tem pontos comuns com outros casos ocorridos em Portugal nos últimos 200 anos : a revolução liberal de Agosto de 1820 , o movimento da Regeneração de 1851 e o 28 de Maio de 1926. Exclui , numa primeira apreciação, o 5 de Outubro de 1910. E invoca várias razões de identidade entre as citadas 4 ocorrências com vista a definir uma tipologia categorial para as mesmas e que é a de " movimentos patrióticos das forças armadas " ou movimentos militares de salvação nacional "52 - Não vamos discutir os aspectos comuns referidos pelo Autor. Realçamos apenas que existe um aspecto, pelo menos, que este Autor não valoriza e que nos parece decisivo para afastar por completo o 25 de Abril das restantes experiências revolucionárias de mudança constitucional nos secs. XIX e XX quer lideradas pelas Forças Armadas quer por civis: justamente a marcada preocupação constitucionalista e civilista e o cuidado posto na transição jurídicopolitica. E isso decorre, justamente, do Programa do MFA, sem equivalente em qualquer dos outros momentos .

O mesmo Autor salienta que " uma das vantagens do movimento de Abril para derrubar o antigo poder foi o facto de não ter uma ideologia clara ou um núcleo coerente e coeso que o conduzisse; mas essa foi uma das suas grandes desvantagens quando se procurou edificar um novo poder. O movimento enquanto tal tinha vaga ideia para onde queria ir, onde o único consenso estava na democratização tudo o mais sendo nublado e vago" . E acrescenta : "Qual era a " ideia vaga sobre o caminho a seguir ? Ela era dada pelo Programa do MFA uma manta de retalhos de boas intenções, propositadamente impreciso à partida e algo incoerente depois de múltiplas emendas e acrescentos que sofreu até ser tornado público" 53 . E mais à frente : "(...) o programa do MFA- único documento

51 Vide António José Telo, História Contemporânea de Portugal, Do 25 de Abril à actualidade, vol I, Lisboa, Presença, 2007, p. 31

52 Vide idem, ibidem, p. 39

53 Vide idem, ibidem, p. 43 
orientador geral- era vago e impreciso em termos dos dois problemas mais prementes : o tipo de democracia que se pretendia e as guerras de Africa"54 .

Acrescenta ainda que o Programa previa a criação de dois centros de poder a muito curto prazo ( 3 semanas) : um militar( Junta de Salvação Nacional ) e outro civil ( Governo Provisório), sendo que a própria Comissão Coordenadora do MFA não estava sequer prevista pudesse existir na estrutura transitória do poder . E conclui " nada demonstra melhor a ingenuidade e falta de experiência politica dos responsáveis pela preparação do 25 de Abril do que a forma amadora como o Programa do MFA tratava o poder do Estado, aspecto central para a concretização de qualquer política" 55 .

Não há como negar a evidência. Ou seja, que o Programa sofreu várias alterações até ser divulgado pela voz de Vitor Alves às $7 \mathrm{~h} 30 \mathrm{~m}$ do dia 26 de Abril, como antes se viu. Acontece que, como se sabe hoje, essas alterações, motivadas sobretudo, na última fase, pela intervenção de Spínola, incidiram quase exclusivamente na questão da Guerra Colonial e na não dissolução da DGS no Ultramar. Toda a estrutura de poder transitória ( com os seus prazos), o compromisso da Constituinte com vista à nova Constituição e as medidas imediatas e de curto prazo, não sofreram alterações significativas, pelo menos desde a versão pré final de Melo Antunes. Ora essa realidade desvaloriza um pouco o argumento das "múltiplas emendas e acrescentos" como razão para a sua alegada incoerência e imprecisão. E também é verdade que o Programa não dava aos seus autores ( e responsáveis materiais pela ruptura politica que acaba de ocorrer), ou seja os jovens capitães organizadas no Movimento das Forças Armadas ( designadamente à sua Comissão Coordenadora) qualquer institucionalização na nova estrutura de poder.

É claro que neste aspecto a discussão gira em torno da mitologia do desapego do poder por parte dos militares de Abril , da sua " pureza" e da defesa de uma " moral " própria que os fez recusar recompensas ou promoções e acreditar que restaurada a democracia pelo acto militar do 25 de Abril, regressariam aos quartéis, deixando aos civis o encargo de fundar a democracia portuguesa.

Suponho que o acabámos de analisar acima, designadamente o destino do Programa do MFA e sobretudo a estrutura de poder que resultou do impulso criado pela Lei $\mathrm{n}^{\circ} 3 / 74$, não elimina o discurso do desapego do poder, mas matiza-o. E sobretudo, se bem o interpretamos, permite infirmar a ideia da incoerência do Programa do MFA e da impreparação dos jovens capitães ( e de quem os assessorava) para congeminar uma solução de poder estável e coerente com vista a ultrapassar com sucesso o período de transição.

54 Vide idem, ibidem, p. 45

55 Vide idem, ibidem, p. 47 


\section{O PAPEL DO PROGRAMA DO MFA COMO ACTO CONSTITUCIONAL DO ESTADO NA FASE TRANSITÓRIA}

O papel do Programa do MFA na nova ordem jurídico-constitucional pese embora a transitória e precária vigência da Constituição de 1933 no imediato pós 25 de Abril, é muito significativo . Ele será a verdadeira Constituição formal e material do período transitório. Desde logo na própria na Lei $n^{\circ} 3 / 74$ onde os seus princípios são elevados à categoria de princípios constitucionais $\left(\right.$ art. $\left.1^{\circ}\right)$, parâmetro de validade da Constituição de 1933 e fonte de interpretação e integração da mesma. E depois , ainda na mesma Lei, outros dois pontos fazem realçar o valor constitucional do Programa do MFA. Por um lado as linhas de orientação governamental do Governo Provisório ( art. $17^{\circ} \mathrm{n}^{\mathrm{o}} 1$ ) devem executar o Programa do MFA e , por outro lado, é também por referência ao Programa que a própria Junta de Salvação Nacional (art. $10^{\circ} \mathrm{n}^{\circ} 1$ ) se vincula no exercício das suas competências de vigilância.

Parece claro que nesta fase do novo ordenamento jurídico o Movimento das Forças Armadas, e em rigor a sua Comissão Coordenadora são o verdadeiro poder constituinte dotados de poderes reais de "indirizzo político" 56 , quer como autores do Programa do MFA que assume natureza de acto constitucional do Estado, quer na designação dos membros da JSN que recebem mandato expresso do MFA, quer ainda na presença de sete membros militares no Conselho do Estado designados pelo MFA ${ }^{57}$.

A verdade é que os órgãos de poder constitucional transitório ( em particular a JSN ) exercem o poder por vida de delegação do MFA que conserva a titularidade do poder constituinte. A legitimidade revolucionária invocada pela Junta era uma simples legalidade derivada. A legitimidade originária pertencia ao MFA e Junta reconhecia-o 58

O Programa do MFA assume força vinculativa para os órgãos do Estado. A própria Constituição de 1933 apenas se mantêm em vigor no que não contrariar os princípios expressos do Programa do MFA e as suas disposições na parte que subsistirem e as lacunas serão interpretados e integradas também de acordo com aquele documento ( $\operatorname{art.} 1^{\circ} n^{\circ} 1$ e 3 da Lei $\left.n^{\circ} 3 / 74\right)^{59}$

Mas a verdade é que o Programa do MFA foi decisivo quanto à configuração do procedimento constituinte que levou à aprovação da Lei Fundamental de 1976 e resolve algumas questões acerca do debate constitucional em torno da justiça procedimental constituinte. Como escreve Gomes Canotilho “ a elaboração do texto de 1976 obedeceu ao paradigma clássico da soberania constituinte e da democracia dualista: (1) eleição de deputados constituintes segundo as regras do

56 Vide Giuseppe Vergottini,op.cit. p. 157

57 Há quem assinale, para confirmar o papel constituinte da Comissão Coordenadora do MFA a proclamação divulgada na rádio a 25 de Abril, o comunicado lido por Spínola na madrugada do dia 26 e o programa do MFA . Vide Giuseppe Vergottini, op.cit. p. 24

58 Vide Miguel Galvão Teles,op.cit. p. 595

$59 \mathrm{O}$ que permite falar em novação jurídica, no que toca ao destino da Constituição de 1933. Ou seja ela permanece- no que não for incompatível com os princípios do Programa do MFA mas a fonte da legitimação é agora o Programa do 25 de Abril e já não o 28 de Maio de 1926. Nesse sentido fala-se em recepção material . Vide Giuseppe Vergottini,op.cit. p. 208 
sufrágio universal, igual, directo e secreto; (2) formação de uma assembleia constituinte exclusivamente competente para a feitura de uma lei fundamental ; (3) atribuição de soberania constituinte a essa assembleia, pois a ela competiria não apenas a feitura do texto mas também a aprovação em termos definitivos ( técnica da assembleia constituinte soberana) “60

Ou seja a solução de elaboração e aprovação da futura Constituição através da Assembleia Constituinte era justamente o procedimento descrito no Programa do MFA ( Ponto B-5) que assim transitou para a Lei $\mathrm{n}^{\circ} 3 / 74$. Como também escreve Gomes Canotilho "a Lei $n^{\circ} 3 / 74$ levou à risca os ensinamentos da teoria do poder constituinte" 61. Acrescentaremos nós que essa teoria havia sido já exemplarmente perfilhada pelo Programa do MFA. Nesse contexto a discussão em torno da injustiça procedimental pela via da não sujeição da nova Constituição a referendo não pode sequer colocar-se à luz do que vem de dizer-se. O programa do MFA não previa qualquer referência à participação popular referendária na aprovação do novo texto constitucional. É claro que a questão do referendo constituinte - que havia sido já colocada, como vimos, por ocasião da " crise Palma Carlos" - veio a ser reaberta como forma de ultrapassar uma alegada ilegitimidade material da Constituição amarrada a limites materiais contingentes e à falta de liberdade da Assembleia Constituinte62. Mas essa é outra questão. Em boa verdade a "invenção do problema do referendo" só se colocou após a aprovação da Constituição e ela serviu como estratégia de combate contra a legitimidade da Constituição. Mas a partir do momento em que o Programa do MFA opta por um modelo de poder constituinte clássico 63 , podendo naturalmente ter optado por outro em que após a discussão em Assembleia do texto constitucional a sanção final incumbiria ao povo através de referendo, como foram os casos de França em 1946 ou de Espanha em 1978, não é possivel falar de qualquer injustiça procedimental constituinte ${ }^{64}$.

60 José Joaquim Gomes Canotilho, Direito Constitucional e Teoria da Constituição, $7^{\mathrm{a}}$ ed. Coimbra, Coimbra Editora, 2003 , p. 200

61 Vide idem, ibidem, p. 201

62 Vide Francisco Lucas Pires , A Constituição de 1976 . A Transição dualista, Coimbra 1989, p. 125

63 Vide José Joaquim, Gomes Canotilho, op.cit., p. 79

64 Aliás a questão da injustiça procedimental pode colocar-se - e colocou-se efectivamente - em relação a Constituições que hoje têm aura de intocáveis e de que ninguém objectivamente questionará a sua essência materialmente democrática como é o caso por exemplo da Lei Fundamental de Bona. Como dizia Karl Loewenstein os formuladores da "Grungesetz" exibiram uma profunda descrença do povo, na justa medida em que aquela foi o produto da derrota militar e da ocupação dos aliados que tiveram influência decisiva no momento constituinte . Vide Andrew Arato, "Construção Constitucional e teorias da Democracia" , Lua Nova, n 42, 1997 , p. 10 


\subsection{O Programa do MFA e as Leis Constitucionais transitórias}

A expressa invocação do Programa do MFA ocorre em muitas Leis Constitucionais( quer nos respectivos preâmbulos quer no articulado) a saber : Lei $\mathrm{n}^{\circ} 1 / 74$ de 25/4 ( Preâmbulo), Lei 3/74 de $14 / 5$ ( Preambulo e arts. $1^{\circ} \mathrm{n}^{\circ} 1$, $7^{\circ} \mathrm{n}^{\circ} 3$ e $17^{\circ} \mathrm{n}^{\circ} 1$ ), Lei $4 / 74$ de $1 / 7$ ( Preâmbulo), Lei 5/74 de $12 / 7$ ( art. $3^{\circ}$ ), Lei $\mathrm{n}^{\circ} 7 / 74$ de $27 / 7$ ( preambulo e art. $1^{\circ}$ ), Lei $\mathrm{n}^{\circ} 2 / 75$ de $31 / 1$ ( Preambulo), Lei 3/75 de 19/2 (Preambulo), Lei 5/75 de 14/3 (preâmbulo e art. $2^{\circ} \mathrm{n}^{\circ} 1$ al. e), Lei 6/75 de 26/3 (art. $4^{\circ}$ ) ; Lei $n^{\circ} 10 / 75$ de $7 / 8$ ( art. $3^{\circ}$ ) ; Lei $n^{\circ} 17 / 75$ de 26/ 12 ( Preambulo ) . Como se referiu o poder de aprovar leis com valor constitucional estava atribuído por força da Lei $n^{\circ} 3 / 74$ ao Conselho de Estado e após a Lei $n^{\circ}$ 5/75 ao Conselho da Revolução.

Do ponto de vista material Jorge Miranda assinala que a ideia de Direito sofreu ao longo deste período variações que se arrumam em 3 períodos. Assinala que até à Lei $\mathrm{n}^{\circ} 5 / 75$ de $14 / 3$ a ideia de Direito se centrou no Programa do MFA e na Lei $n^{\circ} 3 / 74$, da Lei $n^{\circ} 5 / 75$ até à Lei $n^{\circ} 14 / 75$, ou seja até ao 25 de Novembro, a ideia de direito ainda está " de certa maneira no Programa do MFA mas também e cada vez mais em leis avulsas constitucionais e ordinárias" e finalmente com Lei $n^{\circ} 15 / 75$ e a Lei $n^{\circ} 17 / 75$ até à aprovação da Constituição o projecto político volta a ser o programa do MFA " interpretado e revivido de harmonia com estas duas leis e conjugado com as Leis $n^{\circ} \mathrm{s} 3 / 74$ e 5/75" 65 .

O mesmo Autor 66 refare algumas notórias desconformidades das Leis Constitucionais com o Programa do MFA . A Lei $n^{\circ}$ 5/75 na medida em que previa como competência do $\mathrm{CR}$ legislar para as necessárias reformas de estrutura da economia portuguesa conflituava com o ponto B5 do Programa do MFA quando este previa que "as grandes reformas de fundo só poderão ser adoptadas no âmbito da futura Assembleia Nacional Constituinte". O mesmo se diga da concentração de poderes no CR quando o Programa previa dois órgãos , a JSN e o Conselho de Estado ( B.1. B.3 e C.1) e era ao Governo que competia lançar os fundamentos de uma nova politica económica e social( B.6) . Mais grave ainda seria o teor da Lei $n^{\circ} 15 / 75$ ao instituir um Tribunal Militar Revolucionário para os implicados na intentona do 11 de Março , prevendo um processo com diminuição das garantias de defesa quando o Programa consagrava expressamente que " os crimes contra o Estado no novo regime serão instruídos por juizes de direito e julgados em tribunais ordinários sendo dadas todas as garantias de defesa aos arguidos " ( B. 5 e) 2) . E finalmente a Lei $n^{\circ} 11 / 75$ ao prever limitações ao exercício do direito de informação através dos órgãos de comunicação social sobre unidades ou estabelecimentos militares punha em causa o ponto B.5 c) do Programa.

Diferentemente deve ser considerado o caso da Lei $\mathrm{n}^{\circ} 7 / 74$ de 27/6 relativa ao reconhecimento do direito dos povos à autodeterminação. Aí , em face da redacção ambígua do ponto B. $n^{\circ} 8$ al.a) do Programa, que na versão definitiva do Programa ficou desacompanhada de um sentido óbvio, de acordo com as alterações de última hora sugeridas por Spínola, como vimos, houve necessidade

65 Vide Jorge Miranda, A Constituição de 1976, cit,pp. 53-54

66 Vide idem, ibidem, pp. 44-45 
de consagrar a expressa previsão da independência dos territórios ultramarinos e a derrogação do art. $1^{\circ}$ da Constituição de 1933.

Outras das Leis Constitucionais que suscitou vivo debate foi a Lei $n^{\circ} 3 / 75$ que ampliou os poderes legislativos da JSN. Desde logo o PPD reagiu sustentando que " a atribuição de poderes legislativos à JSN revoga com efeito a lógica intrínseca que presidiu à criação do Governo Provisório Civil, nos termos do qual todas as medidas legislativas devem resultar de decisões temperadas pelo confronto de várias correntes politicas significativas com assento no Colégio Governamental " 67. A JSN viu-se forçada a responder para sustentar a compatibilidade da alteração com o Programa do MFA : " A competência legislativa atribuída à JSN encontra-se restringida a campos perfeitamente definidos nos quais não era ainda possivel ao Governo Provisório elaborar a necessária legislação, o que é absolutamente devido á necessidade imperiosa de fazer incidir a sua atenção sobre os assuntos prementes. Desta forma não pode de forma alguma a atribuição de poderes legislativos à Junta de Salvação Nacional ser interpretada como interferência no campo governativo, tanto mais que este como provisório que é recebeu o seu mandato do MFA que através do seu órgão supremo institucionalizado não poderia deixar de colaborar decididamente na implantação da democracia consignada no seu Programa caso tal se verificasse necessário" E adiante: " A atribuição de competência legislativa à Junta de Salvação Nacional em nada altera o pacto contido no Programa do MFA. Com efeito o $n^{\circ} 2$ do art. $19^{\circ}$ da Lei Constituinte $n^{\circ} 3 / 74$ estabelece que compete à JSN vigiar pelo cumprimento do Programa do MFA ". Ora a vigilância não se pode compreender apenas como uma tomada permanente de atenção ao que se passa mas contém implicitamente uma capacidade sempre que as circunstâncias o Imponham".

Contudo, se é certo que o Programa do MFA, embora invocado por todos e em todas as circunstâncias, foi óbvia e ostensivamente contraditado nos casos antes assinalados, por benévola e aberta que possa ser a interpretação que dele façamos, num ponto, e esse é um aspecto fundamental, funcionou como uma verdadeira Constituição normativa : no compromisso relativo à realização das eleições para a Assembleia Constituinte. Note-se que a Lei que alterou o art. $4^{\circ}$ da Lei $n^{\circ} 3 / 74$ de 14/5 relativa à data limite para a realização das referidas eleições, e que era inicialmente 31 de Março de 1975, teve a preocupação de se fundamentar expressamente no Programa " que estipula que as eleições para a Assembleia Nacional Constituinte se terão de realizar no prazo de 12 meses". E na realidade as eleições inicialmente marcadas pelo Presidente da República Costa Gomes para 12 de Abril realizaram-se mesmo a 25 de Abril e portanto no limite do lapso de tempo previsto no Programa do MFA.

Cremos que este ponto merece toda a relevância e não será exagerado dizerse que a realização das eleições para a Assembleia Constituinte - que acabaram por marcar um ponto de viragem decisivo na lógica da transição política, afirmando a legitimidade democrática dos partidos políticos como contraponto à legitimidade revolucionária do MFA e , sobretudo, exibindo o inapagável pluralismo do povo português - se deve ao Programa do MFA. A promessa inicial cumpriu-se, mas isso só se tornou possivel, no contexto das fortíssimas correntes político-militares que advogavam o adiamento das eleições, pelo

67 Cfr. Vida Mundial, 13/3/75 p. 45 
atávico respeito que o Programa do MFA, como verdadeira Constituição da transição, a todos acabou por infundir. Ora esta é também, à luz da teoria da Constituição uma das funções da Constituição política do Estado. A legitimidade do texto, decorre muitas vezes do sistema de crenças que se impõe à comunidade e sobretudo aos detentores do poder politico.

Mas aquela que parece ser a mais óbvia contradição com o Programa do MFA e acabou por se projectar no texto da Constituição de 1976, foi a existência de um período de transição durante o qual subsistiriam órgãos políticos militares formalizado pela via dos Pactos MFA/ Partidos. A verdade é que o Programa era bem enfático ao afirmar que " logo que eleitos pela Nação a Assembleia Legislativa e o novo Presidente da República será dissolvida a Junta de Salvação Nacional e acção das Forças Armadas será restringida à sua missão específica de defesa da soberania nacional " ( C.1)

\subsection{A legislação transitória como execução do Programa do MFA}

E é claro que grande parte da legislação não constitucional do período transitório, mas que se reveste de extrema importância quer pelo impacto que teve na evolução dos acontecimentos económicos e sociais consagrando juridicamente o que decorria dos factos, quer alterando profundamente partes significativas do ordenamento jurídico português ( nos direitos fundamentais e na organização económica e social), oriunda quer do Governo Provisório , quer do Conselho da Revolução, invocam o Programa do MFA. Alguns exemplos :

a) um dos diplomas que procura, um mês a seguir ao 25 de Abril, dar resposta a algumas questões urgentes de ordem social e económica e que procura cumprir o compromisso de corrigir os desequilíbrios sociais e económicos como tal definido no Programa do MFA é o Dec.Lei $n^{\circ} 217 / 74$ de $27 / 5$, que entre muitas outras medidas fixa o salário mínimo nacional em 3.300 $\$ 00$, aumenta o abono de família e cria uma pensão social para os que não estavam incluídos nos regimes de previdência ( I Governo Provisório) ;

b) o diploma que dá execução às medidas previstas no Programa relativas à independência e dignificação do Poder Judicial ( Dec. Lei 261/74 de 18/6) que também refere ser aprovado " dando cumprimento ao Programa do MFA"( I Governo Provisório) ;

c) o Dec. Lei $n^{\circ} 375 / 74$ de 20/8 que constitui a primeira " reforma fiscal" pós 25 de Abril e que expressamente invoca o " Programa do MFA" , considerando-o mesmo " lei constitucional"; ( I Governo Provisório) ;

d) o Dec. Lei $n^{\circ} 392 / 74$ de 27 /8 relativo ao Direito à greve e " Lock-out" e que invoca a " ruptura da ordem politica vigente até ao dia 25 de Abril que implica a revogação do regime de proibição da greve e do "lock out" em consonância aliás com o reconhecimento das associações sindicais e patronais e dos princípios que encontram expressão adequada no Programa do MFA parte integrante da nova ordem constitucional"( II Governo Provisório) ;

e) o Dec. Lei $n^{\circ} 406 / 74$ de 29/8 relativo ao direito de reunião e manifestação que no seu preâmbulo refere : " A fim de dar cumprimento ao disposto no 
Programa do Movimento das Forças Armadas, B $n^{\circ} 5$ alinea b) " ( II Governo Provisório ) ;

f) o Dec. Lei $n^{\circ}$ 621-A/ 74 de 15/11 relativo ao recenseamento eleitoral que tratando de matéria essencial para a realização das eleições para a Assembleia Constituinte é enfático quanto ao " imperativo constitucional" que nessa parte resulta do programa do MFA;( III Governo Provisório) ;

g) o Dec.Lei $\mathrm{n}^{\circ}$ 85-C/ 75 de 26/2 que se reporta à " Lei de Imprensa" que claramente refere o " Programa do Movimento das Forças Armadas que tem força de lei constitucional "( III Governo Provisório) ;

h) o Dec. lei n ${ }^{\circ}$ 132-A/ 75 de 14/3 que nacionalizou todas as instituições de crédito que no seu preâmbulo refere " a necessidade de concretizar uma politica económica anti-monopolista que sirva as classes trabalhadoras e as camadas mais desfavorecidas da população portuguesa, no cumprimento do Programa do MFA" ( Conselho da Revolução) ;

i) o Dec. Lei $n^{\circ} 135-A / 75$ de $15 / 3$ que nacionalizou as companhias de seguro, cita no preâmbulo o " cumprimento do programa do MFA"( Conselho da Revolução) ;

j ) o Dec.Lei $n^{\circ} 201 / 75$ de 15 de Abril que consagra um novo regime de arrendamento rural e que também se acolhe à lareira dos "princípios e directrizes do Programa do Movimento das Forças Armadas" ( IV Governo Provisório) ;

h) o Dec.Lei $\mathrm{n}^{\circ} 42 / 76$ de 20/1 , que determina a expulsão das Forças Armadas dos " implicados no golpe contra-revolucionário de 25 de Novembro que se furtaram ou venham a furtar-se às suas responsabilidades por se terem ausentado dos seus locais de serviço ou que deixem de se apresentar quando para tal sejam convocados" fundamenta tal sanção no facto dos militares " contra-revolucionários" terem actuado em " manifesta oposição ao Programa do Movimento das forças Armadas" ( Conselho da Revolução) ;

1) e até mesmo quando se tratou de adaptar o Código Civil em sede de Direito da Familia após a alteração da Concordata concretizada a 15/2/75 por acordo com a Santa Sé, o Governo provisório se viu compelido a explicar que só não concretizou mais cedo essa alteração porque estava vinculada à Concordata cujo " respeito se lhe impunha por virtude do disposto no Programa do Movimento das Forças Armadas"- ver Dec.Lei 261/75 de 27/5 ( IV Governo Provisório) ;

Ou seja por aqui se constata que a legislação oriunda dos seis Governos provisórios ou do Conselho da Revolução nos dois anos da fase revolucionária, não deixarora nunca, embora em contextos político-militares diversos e por vezes contraditórios- mas que atravessam todas as fases do PREC- de devotar um respeito quase supersticioso ao Programa do MFA. Ele veio a ser considerado como verdadeira Magna Carta do processo político transitório, chegando mesmo a ser considerado " lei constitucional " ou " parte integrante da ordem constitucional" . 
O Programa do MFA, como " Constituição da revolução", teve uma extraordinária força simbólica, a ponto de nenhum grupo político-militar , tendência ou partido político ter proposto a sua expressa supressão ou sequer desvalorização e pelo contrário ter sido sempre a bandeira política, ideológica e constitucional de todos. Mas, forçoso é constatar que não teve apenas expressão simbólica. Ao invés do que alguns sustentam acabou ter verdadeira natureza normativa. Ou pelo menos muito mais normativa do que nominal ou semântica. A prova é que boa parte da legislação do período transitório foi elaborada em cumprimento do Programa do MFA projectando-se de forma directa, como adiante se verá, na própria Constituição de 1976.

\subsection{O Programa do MFA, as decisões pré-constituintes e a Teoria do Poder Constituinte}

Ou seja, quer na sua representação formal no contexto do debate político e do debate parlamentar na Assembleia Constituinte, quer como "norma normarum " que se impôs e é invocada pelas leis constitucionais do período transitório e pela numerosa legislação ordinária ( que aliás é aprovada por sua expressa determinação) o Programa do MFA foi uma verdadeira Constituição Politica .

O que importa agora ver é que tipo de Constituição ela foi no contexto da Teoria da Constituição e quais as suas especificidades por referência ao seu modo de elaboração, critérios, conteúdo, forma e funções.

$\mathrm{Na}$ teoria da Constituição é usual aferir-se a Constituição dos tempos modernos segundo critérios materiais e formais. Pela primeiro o conceito remete para as regras essenciais do Estado e dos seus elementos, ou seja para a forma do Estado, para a organização dos poderes públicos e constituídos( organização politica assente no princípio da separação de poderes ) e para a consagração e garantia dos direitos fundamentais dos cidadãos. Do ponto de vista formal a Constituição remete para o seu processo de elaboração, o seu nascimento. A concepção clássica construiu o modelo de poder constituinte como manifestação distinta e superior no quadro do Estado, com natureza originária e fundadora. Formalmente a Constituição não é mais e não é apenas uma lei é a Lei Fundamental e tal decorre da superioridade e particularidade do seu processo criador, que as mais das vezes se projecta no seu procedimento de revisão. Por ser superior a Constituição exige uma mecanismo de controle das normas ordinárias, controle esse que começou por ser de natureza politico mas que hoje tem prevalência jurisdicional : o controlo da constitucionalidade das normas. Em regra conteúdo e forma coincidem ( e só assim não será em sistemas constitucionais onde os principios constitucionais assentam em fontes costumeiras que convivem com fontes escritas que é o caso do Reino Unido) . Mas a Constituição, composta por princípios e regras jurídicas escritas ( e algumas não escritas) nasce como resultado do exercício do poder constituinte. Este é incondicionado e apresenta-se como um fenómeno de facto ( revolucionário ou não ) contrário à ordem jurídica anterior. A nova ideia de Direito que pode traduzir-se em ruptura mais ou menos profunda com a anterior é exercida por quem ficou a deter efectivamente o novo poder politico. Esse novo poder pode abrir caminho ao exercício não democrático do poder constituinte ( como aconteceu com as Constituições outorgadas pelo Monarca, pactadas entre o 
monarca e uma Assembleia Constituinte ou sujeitos a consultas populares cuja democraticidade é contestada) ou ao exercício democrático ( pela via da Assembleia Constituinte com ou sem intervenção posterior do povo através de referendo constituinte).

Quais as funções da Constituição ? É usual afirmar-se que elas cumprem funções jurídicas e políticas. Funções jurídicas no triplo sentido de : a) são o fundamento da validade da ordem jurídica global, já que a Constituição é o fundamento das normas que fazem parte da ordem jurídica b) determina a modalidade de designação dos governantes e atribui as suas competências ; c) enuncia os princípios relativos à soberania, à representação e à separação de poderes;

Do ponto de vista político a Constituição, por um lado, organiza a transmissão e exercício do poder e por outro é o fundamento da legitimidade dos governantes, em termos tais que os governantes podem justificar o seu poder e as suas decisões pelo facto de terem sido designados de acordo com a Constituição e exercerem os poderes também conferidos por ela.

O que acaba de dizer-se decorre de uma teoria da Constituição muito centrada no procedimento constituinte e nas decisões constituintes formais. A esta luz o Programa do MFA tem alguma dificuldade em encontrar um paradigma de referência. Ora como escreve Gomes Canotilho 68 " em rigor o primeiro acto constituinte situa-se ainda no terreno pré-constituinte, pois ao acto de atribuição constituinte pertence decidir como é que o povo vai adoptar a lei fundamental... ". Faltaria então uma teoria de decisões pré-constituintes.

Assim os Autores aludem a " pequenas constituições" transitórias, pré constituições, constituição provisória ou constituição revolucionária ${ }^{69}$

A verdade é que os momentos constitucionais extraordinários ( revoluções, transições, nascimento de novos Estados) implicam decisões pré-constituintes. Decisões politicas de elaborar e como elaborar a nova Constituição e decisões constitucionais para a fase transitória até que a nova Constituição entre em vigor . É então possivel falar de: a) um momento desconstituinte traduzido na revogação total ou parcial da Constituição antiga; b) decisão atributiva de poder constituinte ( a uma Assembleia Constituinte) ; c) leis constitucionais transitórias ${ }^{70}$.

A novidade do Programa do MFA, neste modelo, é que ele consome os três momentos antes assinalados : é a um tempo a nova ideia de Direito que revoga a anterior, quem decide do modo de exercício do poder constituinte para a nova Constituição e quem provê à constitucionalização da transição.

68 Vide José Joaquim Gomes Canotilho,op.cit. p. 74

69 Vide Jorge Miranda, Manual de Direito Constitucional, Tomo II , $6^{\circ}$ ed., Coimbra, Coimbra Editora, 2003, p. 108

70 Vide José Joaquim Gomes Canotilho, op.cit. p. 74 


\subsection{O Programa do MFA, a Assembleia Constituinte e a Constituição de 1976}

Um dos pontos em que a irradiação do Programa no processo políticomilitar se mostra decisiva para a fase transitória é nas eleições para a Assembleia Constituinte. Ou seja, o objectivo de eleger uma Assembleia Constituinte sempre se manteve como prioritário e foi sempre declarado em todas as revisões politicas que se deram até ao dia 25 de Abril de 1975 e algumas delas bem dramáticas, como já vimos ${ }^{71}$. É certo que se ouviram vozes a favor do adiamento das eleições e é provável que houvesse quem assumisse nesta altura um propósito vanguardista em que as eleições deveriam sair de cena para permitir um estado de revolução permanente. Contudo é razoável concluir que não era essa a opinião da maioria dos membros do Conselho da Revolução e sobretudo do Presidente Costa Gomes, que entendia fundamental a realização das eleições como garante da liberdade estratégica das próprias Forças Armadas ${ }^{72}$.

Questão diversa - e aí o Programa do MFA também serviu de bandeira - era a da estratégia do PCP e dos seus aliados na liderança do MFA quanto à lógica do processo revolucionário : " O processo revolucionário iniciado a 25 de Abril não acaba nem pode acabar com as eleições para a Constituinte, o Programa do MFA é nisto muito claro ao afirmar no seu ponto 3-a) que o período de excepção terminará logo que de acordo com a nova Constituição Política estejam eleitos o Presidente da República e a Assembleia Legislativa " isto significa que até lá e portanto durante todo o ano de 1975 a direçção do processo compete ao MFA" liase num texto publicado no Boletim do MFA de 14/1/1975 73

É também a esta luz que importa ver das relações entre a a Constituição de 1976 e o Programa do MFA. Na verdade, a Constituição na sua redação originária, refere expressamente o Programa do MFA no art. $273^{\circ} \mathrm{n}^{\circ} 2$ quando aí se estipulava que as " Forças Armadas Portuguesas são parte do povo e identificadas com o espírito do Programa do MFA asseguram o prosseguimento da Revolução de 25 de Abril de 1974". Mas os arts. $142^{\circ}$ e 147 relativos à definição e competência do Conselho da Revolução referem que este órgão de soberania é o garante da fidelidade ao espírito da revolução portuguesa de 25 de Abril de 1974.

A este propósito Jorge Miranda sustenta que " com a formulação doutrinária da revolução que derrubou o regime da Constituição de 1933 , o Programa encerrava uma ideia de Direito que seria impensável ver afastada pela Assembleia Constituinte(...) contudo as circunstâncias ( ...) vieram a realçar a participação da Assembleia na formação e revelação da ideia de Direito. Pois que não tendo sido homogéneo o periodo revolucionário, tendo-se verificado leituras diferentes do Programa e tendo havido antagónicos projectos de revolução a procurar impôr-se acabou por ser a Assembleia a tornar clara a opção primeira e definitiva em correspondência com o resultado das eleições de 25 de Abril de 1975. Foi a Assembleia Constituinte que faz a interpretação autêntica do Programa do MFA; e havia de ser essa interpretação e não a feita por ninguém mais que haviam de reportar-se os preceitos constitucionais alusivos ao " espírito

\footnotetext{
71 Vide Medeiros Ferreira,op.cit. .pp. 200-201

72 Vide idem, ibidem, p. 207

73 Vide idem, ibidem, p. 205
} 
da revolução de 25 de Abril ou ao Programa do MFA" 74 75. Daí que segundo este Autor, enquanto que o Programa do MFA traduziu o poder constituinte material - a nova ideia de Direito- como resultado directo e imediato do 25 de Abril a Constituição de 1976 traduziu o exercício simultâneo do Poder constituinte formal e material que interpretou autenticamente aquela ideia de Direito ${ }^{76}$

$\mathrm{Na}$ mesma linha, quando a versão originária estipulava que o MFA como garante das conquistas democráticas e do processo revolucionário participava em aliança como o povo no exercício da soberania nos termos da Constituição ( art. $3^{\circ} \mathrm{n}^{\circ}$ ) ou quando garantia que a aliança entre o MFA e os partidos politicos e as organizações democráticas assegurava o desenvolvimento pacífico do processo revolucionário ( art. $\left(10^{\circ} \mathrm{n}^{\circ} 1\right.$ ) o esforço de interpretação desses preceitos , afastando qualquer vanguardismo politico-militar por contrário ao " Programa do MFA" e enquadrando-os numa lógica de legitimidade democrática, foi em boa medida uma tarefa bem sucedida da Assembleia Constituinte ${ }^{77}$

Em bom rigor a questão remete para saber se a Assembleia Constituinte estava limitada pelo Programa do MFA, quando este the impunha a elaboração de uma Constituição e apenas isto. Aliás, as Leis Constitucionais 3/74 e 5/75 vieram a precisar que a Assembleia Constituinte não podia fazer leis ordinárias ou agir sobre o Governo e também não tinha poderes para aprovar leis constitucionais para o período transitório até à aprovação da nova Constituição. Sabemos que com excepção do periodo de antes da ordem do dia - cuja influência politica foi manifesta- e dos requerimentos dirigidos ao Governo sobre assuntos correntes de política e administração pública, a Constituinte apenas debateu e votou a Constituição 78 .

Mas essa foi uma discussão que tendo extravasado, é certo, o plenário da Assembleia Constituinte teve nela a maior repercussão. Quer a propósito da consagração regimental do Período de Antes da Ordem do Dia quer a propósito do acompanhamento por parte da Comissão do MFA dos trabalhos da Assembleia Constituinte ouviram-se vozes contraditórias sobre a natureza soberana da Assembleia e o fundamento da sua legitimidade. A intervenção decisiva - porque historicamente vencedora - que marca a afirmação da legitimidade democrática e soberana da Constituinte é a de Jorge Miranda( como deputado constituinte do PPD) : " Custa-me nesta altura que ainda haja quem duvide que a Assembleia Constituinte é um órgão de soberania. Parece evidente que não pode haver algum outro órgão mais soberano que o que faz a Constituição. Todavia queria explicar que esta soberania da Assembleia decorre directamente da revolução , não há contradição de espécie alguma entre a soberania em que se encontra investida a Assembleia Constituinte e a Revolução Portuguesa. Pelo contrário a

74 Vide Jorge Miranda, Manual de Direito Constitucional, Tomo II, $5^{\circ}$ ed. ,Coimbra, Coimbra Editora, 2003, pp. 92

75 No mesmo sentido José Joaquim Gomes Canotilho e Vital Moreira, Constituição da República Portuguesa Anotada, Coimbra, Coimbra Editora, 1980, p. 302

76 Note-se que o Regimento da Assembleia Constituinte logo no seu art. $1^{\circ}$ referia que a existência da Assembleia Constituinte era a " concretização do Programa do MFA"

77 Vide Jorge Miranda, “A participação dos Militares no exercício da Soberania” in Estudos sobre a Constituição, vol. II, Lisboa, Livraria Petrony, 1978, p. 47

78 Vide Jorge Miranda, Manual de Direito Constitucional, tomo I, cit. p. 345 e ss 
legitimidade que esta assembleia tem decorre directamente da Revolução Portuguesa. Essa legitimidade revolucionária, essa soberania em que se encontra investida a Assembleia encontra-se consagrada no Programa do MFA, na Lei 3/74 , na Lei 5/75..."79

Aliás, a invocação do Programa do MFA na Assembleia Constituinte curiosamente à medida que a situação se radicalizava muito mais citado pelos Deputados do PS, PPD e $\mathrm{CDS}^{80}$ - serviu também para desde o início legitimar a própria eleição dos Deputados, ao se enfatizar que a eleição constituinte traduziu o" cumprimento honrado do Programa do MFA"81 e que a constituição da Assembleia de acordo com o mandato do povo foi realizada em "conformidade com o Programa do MFA"82 e para salientar que a Constituição futura " não se afaste do espírito do Programa do MFA"83.

Na verdade e como confessava o Deputado José Luis Nunes (PS) " nos temas e debates desta Constituição (...) temos tocado constantemente o problema de que aqui há partidos, há pessoas que são melhores intérpretes do que outras do Programa do MFA" 84

Após este excurso a pergunta que legitimamente se pode colocar é a de saber se e em que medida o Programa do MFA constituiu fonte da Constituição de 1976. A pergunta não é inócua sobretudo se tivermos em consideração que a generalidade da nossa doutrina constitucionalista desvaloriza a questão , embora admita que ele possa ser considerado uma fonte indirecta 85 .

Mas julgamos que teremos de ir um pouco mais longe. Nesse sentido talvez a expressão " influência sobre a normatividade constitucional "86 permita traduzir com mais rigor o sentido da influência do Programa do MFA na Constituição de $1976^{87}$

$\mathrm{Na}$ verdade alguns principios e normas da Constituição resultaram da legislação do período transitório como decorrência expressa do Programa do MFA.

79 Cfr. Diário da Assembleia Constituinte n $11,24 / 6 / 1975$ p. 240

80 Talvez porque como se expressava Etelvina Lopes de Almeida ( PS) " fala-se cada vez menos do Programa do MFA " outros textos, alguns de carácter anti-democrático vieram marginalizá-1o" Diário da Assembleia Constituinte, n 26 6/8/1975 p. 645

81 Cfr. Barbosa de Melo (PPD) Diário da Assembleia Constituinte n ${ }^{\circ} 5$ de 14/6/1975 p. 61

82 Cfr. Mota Pinto ( PPD) Diário da Assembleia Constituinte n ${ }^{\circ} 2$ 4/6/1975 p. 10. Também Marcelo Rebelo de Sousa ( PPD) Diário da Assembleia Constituinte, no 20 de 19/7/1975 p. 480

83 Cfr. Lopes Cardoso ( PS)Diário da Assembleia Constituinte n ${ }^{\circ} 617$ /6/1975 p. 77

84 Cfr. Diário da Assembleia Constituinte, no 11, 24/6/1975 p. 245

85 Vide José Joaquim Gomes Canotilho e Vital Moreira,op.cit.. p. 17

86 Vide Paulo Otero, Direito Constitucional Português, vol I, Coimbra, Coimbra Editora, 2010 , p. 283

87 Paulo Otero assinala a influência do Programa do MFA na normatividade vigente a vários niveis : “ ... a afirmação da liberdade de formação de associações politicas possiveis embriões de futuros partidos políticos além da expressa garantia da liberdade sindical”. E mais adiante “ é aqui ainda, à luz do Programa do MFA que se encontra a definição dos princípios nucleares da política externa portuguesa que, posteriormente viriam a ser acolhidos pelo artigo $7^{\circ}$ da Constituição : os princípios da independência e da igualdade entre os Estados, da não ingerência nos assuntos internos dos outros Estados e da defesa da paz" vide idem, ibidem, p. 284 
O “PROGRAMA DO MOVIMENTO DAS FORÇAS ARMADAS: O SINGULAR...

Alguns dos casos foram antes referenciados, como os atinentes ao Provedor de Justiça, aos direitos e liberdades relativos à comunicação e informação e aos órgãos de comunicação social, à organização económica, aos direitos económicos, sociais e culturais ( segurança social, desemprego, relações laborais) aos direitos relativos à família (divórcio e separação), à estrutura de auto- organização do Poder Judicial e mesmo aos direitos em sede de Direito Penal e garantias de processo penal.

É certo que nem sempre é fácil identificar de forma precisa e directa a fonte das normas constitucionais por referência à legislação do periodo transitório. Mas em alguns casos, porém, é manifesto que a redacção das normas reproduz quase "ipsis verbis" essa mesma legislação.

Alguns exemplos, entre muitos outros :

a) sistema eleitoral para a Assembleia da República ( originário art. $155^{\circ}$ actual art. $149^{\mathrm{a}}$ ) ver o art. $7^{\circ}$ do Dec.Lei $621 / \mathrm{C} / 74$ de 15/11;

b) princípios gerais de direito eleitoral ( originário art. $116^{\circ} \mathrm{n}^{\circ} 5$ e actual $113^{\mathrm{a}} \mathrm{n}^{\mathrm{o}} 5$ ) ver o art. $7^{\circ}$ do Dec.Lei 621-C/74 de $15 / 11$;

c) direito de reunião e manifestação( originário e actual art. $45^{\circ}$, ver os arts. $1^{\circ}$ e $8^{\circ}$ do Dec. Lei $n^{\circ} 406 / 74$ de 29/8;

d) liberdade partidária ( originário art. $47^{\circ} \mathrm{n}^{\circ} 2$ e actual art. $51^{\circ} \mathrm{n}^{\circ} 2$, ver o art. $16^{\circ}$ do Dec.Lei $n^{\circ} 595 / 74$ de $7 / 11$ );

e) Funções dos partidos políticos ( originário art. $3^{\circ} \mathrm{n}^{\circ} 3$ e actual art. $10 \mathrm{n}^{\circ} 2$ ver o art. $1^{\circ}$ Dec-lei $n^{\circ} 595 / 74$ de $7 / 11$ );

f) regras relativas às campanhas eleitorais ( originário art. $116^{\circ} \mathrm{n}^{\circ} 3$ als. b) e c) e actual art. $113^{\circ} \mathrm{n}^{\circ} 3$ b) e c) ), arts. $58^{\circ}$ e $59^{\circ}$ do Dec. Lei $\mathrm{n}^{\circ} 621-\mathrm{C} / 74$ de $15 / 11$ );

g) regras relativas ao recenseamento eleitoral ( originário art. $116^{\circ} \mathrm{n}^{\circ} 2$ actual art. $113^{\circ} \mathrm{n}^{\circ} 2$ ver arts. $16^{\circ}, 17^{\circ}$ e $21^{\circ}$ do DecLei $\mathrm{n}^{\circ} 621-\mathrm{A} / 74$ de $15 / 11$ );

h) direito de sufrágio ( originário art. $48^{\circ} \mathrm{n}^{\circ} 2$ actual art. $49^{\circ} \mathrm{n}^{\circ} 2$ - ver art$84^{\circ} \mathrm{n}^{\circ} 1$ do Dec-Lei $\mathrm{n}^{\circ} 621-\mathrm{C} / 74$ de 15/11);

E em alguns destes casos o debate na Assembleia Constituinte prova essa directa influência. Dois exemplos :

a) a natureza obrigatória do recenseamento ( art. $116^{\circ} \mathrm{n}^{\circ} 3$ ) que o então Deputado Jorge Miranda( PPD) refere como tendo sido consagrada pelo "Governo Provisório" e constando da lei para os actos eleitorais que se "vão realizar em 1976" e que se trata, do seu ponto de vista, de " uma importantíssima conquista do direito português"88;

b) as limitações à liberdade partidária em sede de confundibilidade de denominações, siglas e símbolos( art. $\left.47^{\circ} \mathrm{n}^{\circ} 3\right)$ que o Deputado Carlos Candal ( PS) informa ter sido inspirado no art. $1^{\circ}$ do Dec.Lei $n^{\circ} 126 / 75$ de $13 / 3^{89}$

88 Cfr. Diário da Assembleia Constituinte, $\mathrm{n}^{\circ} 107,4 / 2 / 1976$ p. 3521

89 Cfr. Diário da Assembleia Constituinte n 42 , 4/9/1975 p. 1180-1181 


\section{CONCLUSÃO}

Com excepção da matéria relativa ao sistema de governo, onde o Programa do MFA pouco ou nada dizia por referência ao que deveria ser a nova arquitectura constitucional ( admitia a eleição de uma futura Assembleia Legislativa e do Presidente da República e nada mais ...) em muitas outras matérias a legislação transitória - por directa inspiração do Programa do MFA - acabou por constituir a fonte do texto constitucional ainda que mediada pelos projectos constitucionais dos partidos políticos .

Podemos pois concluir que o Programa do MFA, não foi apenas a Constituição da Revolução do 25 de Abril . Ao garantir a eleição da Assembleia Constituinte e ao ter influência directa na normatividade constitucional que resultou dessa mesma Assembleia foi também uma fonte - e relevante - da Constituição da República Portuguesa de 1976.

\section{bibliografia citada:}

Arato, Andrew. Construção Constitucional e Teorias da Democracia" in Lua Nova, ${ }^{\circ} 42,1997$, pp. 6-52

Canotilho, J.J. Gomes . Direito Constitucional e Teoria da Constituição ( $7^{\mathrm{a}}$ ed.) Coimbra. Almedina, 2003

Canotilho, Gomes \& Moreira, Vital. Constituição da República Portuguesa Anotada, Coimbra. Coimbra Editora, 1980

Cervelló, Josep Sanchez. A Revolução Portuguesa e a sua influencia na Transição espanhola( 1961-1976). Lisboa. Assírio \& Alvim, 1993

Ferreira, Medeiros. História de Portugal ( Direcção de José Matoso). Vol. Oitavo, Lisboa, Círculo dos Leitores, 1994

Marques, Fernando Pereira. "Sete noites, Sete Dias" in Do marcelismo ao fim do Império ( Coordenação de J.M. Brandão de Brito). Lisboa. Notícias Editorial, 1999

Maxwell, Kenneth . A Construção da Democracia em Portugal. Lisboa. Presença, 1999

Miranda, Jorge. A Constituição de 1976. Formação, Estrutura e Princípios Fundamentais . Lisboa. Livraria Petrony, 1978

Miranda, Jorge . Fontes e Trabalhos Preparatórios da Constituição .Vol. II . Lisboa. INCM, 1978

Miranda, Jorge ." A participação dos Militares no exercício da Soberania" in Estudos sobre a Constituição ( Jorge Miranda, org.) , vol II, Lisboa, Livraria Petrony, 1978

Miranda, Jorge. Manual de Direito Constitucional , Tomo I , $7^{\mathrm{a}}$ ed.. Coimbra,Coimbra Editora, 2003 
O "PROGRAMA DO MOVIMENTO DAS FORÇAS ARMADAS: O SINGULAR...

Miranda, Jorge. Manual de Direito Constitucional, Tomo II, $5^{\circ}$ ed. Coimbra, Coimbra Editora, 2003

Otero, Paulo. Direito Constitucional Português . Volume I. Identidade Constitucional, Coimbra, Almedina, 2010

Rezola, Maria Inácia . 25 de Abril . Os mitos de uma revolução. Lisboa. A Esfera dos Livros, 2007

Rodrigues, Avelino, Borga, Cesário \& Cardoso, Mário. O Movimento dos Capitães e 25 de Abril ,( $5^{\mathrm{a}}$ ed.). Lisboa, 2014

Santiago, Maria José Tìscar . O 25 de Abril e o Conselho de Estado. A questão das Actas .Lisboa. Colibri, 2012

Teles, Miguel Galvão. " A revolução Portuguesa e as fontes de Direito" in Portugal O sistema Politico e Constitucional ( Coordenador Mário Baptista Coelho). Lisboa. ICS, 1987

Telo, António José . História Contemporânea de Portugal. Do 25 de Abril à Actualidade, vol. I , Lisboa. Presença, 2007

Thomashausen, André . " Constituição e Realidade Constitucional" in Revista da Ordem dos Advogados, 1977, p. 471 e ss. , 1977

Vergottini, Giuseppe. Le Origine della Seconda Repubblica Portoghese. Milão , 1977

Violante, Luís \& Morais,João. Contribuição para uma Cronologia dos Factos Económicos e Sociais Portugal 1926-1985. Lisboa. Livros Horizonte, 1986

Fecha de envío / Submission Date: 18/06/2015

Fecha de aceptación / Acceptance Date: 23/09/2015 